\title{
Should Compensated Surrogacy Be Permitted or Prohibited?
}

Policy Report Evaluating the New York Child-Parent Security Act of 2017 that Would Permit Enforceable and Compensated Surrogacy

\begin{tabular}{l|l} 
CORNELL INTERNATIONAL HUMAN & NATIONAL LAW \\
RIGHTS: POLICY ADVOCACY CLINIC & UNIVERSITY-DELHI
\end{tabular}

SEPTEMBER 2017 


\section{A PROJECT OF:}

INTERNATIONAL HUMAN RIGHTS:

POLICY ADVOCACY CLINIC, CORNELL

UNIVERSITY LAW SCHOOL

The Cornell International Human Rights: Policy Advocacy Clinic works on a wide array of human rights projects to affect positive policy change in favor of vulnerable and marginalized groups in societies around the world. Law students who participate in the clinic learn lawyering skills such as interviewing, legal research, legal writing, and developing practical solutions to complex problems. Under the supervision of faculty, students conduct fact-finding, in the United States and abroad, and work in teams to conduct impact litigation or produce a policy report designed to affect legislation or other policies

More information about the Clinic can be found at:

http://kalantry.lawschool.cornell.edu/

international-human-rights-policy-advocacyclinic/

TRANSNATIONAL HUMAN RIGHTS SEMINAR, NATIONAL LAW UNIVERSITY, DELHI

The Transnational Human Rights Seminar focuses on foregrounding rights, rightlessness, and other vulnerabilities in understanding, critiquing, and reforming laws, legal institutions, and modes of governance so that they reflect constitutional ideals of justice.

\section{Table of Contents}

\section{EXECUTIVE SUMMARY}

METHODOLOGY

GLOSSARY

CHAPTER 1: THE SURROGACY PROCESS

CHAPTER 2: THE PAST, PRESENT, AND FUTURE OF SURROGACY LAW IN NEW YORK

A. Origins of New York's Prohibition on Surrogacy

B. Description of New York Surrogacy Law

C. Proposed Changes to New York Surrogacy Law: The Child-Parent Security Act

CHAPTER 3: NEW YORK LAW IS AN OUTLIER IN THE UNITED STATES TODAY

A. Comparing New York Law To Surrogacy Laws In Other States.

B. New Yorkers Are Disadvantaged because They Have to Work with Surrogates Out-of-State

C. Comparing the CPSA to Surrogacy Laws in other States

CHAPTER 4: DECREASING RELEVANCE OF THE CONCERNS THAT LED TO THE NEW YORK BAN

Now Technology Are Less Relevant ..............

B. Concerns Relating to The Interests of Children Have Largely Not Been Borne

Out by Surrogacy Practice

C. Concerns Regarding Surrogaty's

D. Concerns Regarding Individual Liberty in Human Reproduction and Attitudes About

Reproduction Can Be Addressed Through Regulation

E. Concerns Regarding Informed Consent Have Largely Not Been Borne Out

And Can Be Addressed Through Regulation

\section{CHAPTER 5: GLOBAL SURROGACY LAWS}

A. Many Countries in Western Europe Adopt a Restrictive Approach to Surrogacy

Based on Religious and Moral Concerns

B. Lack of Regulation and Transnational Demand Led to Abuses in Several

Less Developed Countries

C. Many Countries Permit and Regulate Surrogacy

D. Comparing the CPSA to Global Surrogacy Laws

\section{CHAPTER 6: INTERNATIONAL HUMAN RIGHTS TREATIES SUPPORT LEGALIZATION} OF SURROGACY

A. Surrogacy Does Not Contravene the Rights of Children

B. Permitting Surrogacy Promotes Women's Reproductive Autonomy

C. Surrogacy Allows People to Found a Family

CHAPTER 7: CONCLUSION AND RECOMMENDATION

AUTHORS AND ACKNOWLEDGMENTS 


\section{Executive Summary}

Surrogacy provides a way for infertile people, as well as same-sex couples and single individuals, to become parents. Surrogacy is permitted in most states in the United States. In New York, however, surrogacy contracts are void and unenforceable according to a 1992 law. The Child-Parent Security Act of 2017 (the CPSA) would repeal thi prohibition, make surrogacy agreements enforceable, and permit surrogates to be compensated for the gestational care they provide. In this report, we review the landscape of state laws in the United States, laws around the world moral concerns that led to the adoption of the current New York law, and international human rights considerations that are relevant to evaluating the CPSA. Based on this review, we support the CPSA and suggest some possible additional protections based on practices in other jurisdictions.

NEW YORK LAW IS AN OUTLIER IN THE UNITED STATES TODAY

New York is one of two states in the country that refuse to enforce both compensated and

uncompensated surrogacy arrangements and impose fines and criminal sanctions upon people involved in compensated surrogacy arrangements. Most states explicitly permit or do not have any laws regulating surrogacy. Consequently, New York couples who desire to have children through surrogacy enter into arrangements with surrogates who live and will give birth outside of New York. When New Yorkers go out-of-state this can lead to uncertainty over the law that applies to the arrangement and subsequently the parentage of children. It also leaves New Yorkers to work with professionals who are not accountable to them in New York, and having to conduct any litigation outside of their home state. The result is more complicated and less secure surrogacy arrangements. The CPSA would bring New York in line with other U.S. states and would provide clear legal procedures addressing the parentage of children born through surrogacy arrangements.

\section{DECREASING RELEVANCE OF}

CONCERNS THAT LED TO THE NEW YORK BAN

The current New York surrogacy law was passed based on recommendations of a report published in 1988 by the New York Task Force on Life and the Law (the Task Force). The Task Force raised concerns that surrogacy involved new and relatively untested technology and posed questions about baby selling and the best interest of children, the potential impact of surrogacy on family-life and relationships, individual liberty in human reproduction, attitudes about women, and challenges in ensuring informed consent. Many of the Task Force's concerns are either no longer relevant, due to developments in the practice of surrogacy and in the conception of a family, or have not been borne out. The CPSA contains provisions that address many of the Task Force's concerns that are still relevant today.

\section{GLOBAL SURROGACY LAWS}

Comparative law research supports adoption of the CPSA. There are three primary trends in global surrogacy regulation. First, many countries in

Western Europe consistently prohibit surrogacy because of moral and religious concerns. People in those countries sometimes engage in surrogacy outside of their home country, and the home nations sometimes refuse to recognize the parental standing of intended parents. Second, other countries including Thailand, India, Nepal, and Mexico have moved from a more permissive to a more restrictive approach to surrogacy because of the generally abusive circumstances created by a rapid proliferation in surrogacy over a short period of time and a lack of strong regulation and protection for surrogates and children. The CPSA would provide sufficient regulation to mitigate abuses common in other countries where surrogacy is practiced without regulation. Third, some jurisdictions have moved towards a more permissive approach to surrogacy. Foreign regulatory models and regulatory models in other U.S. states show that successful surrogacy regulation is possible and provide examples for New York.

INTERNATIONAL HUMAN RIGHTS REATIES SUPPORT LEGALIZATION OF SURROGACY

International human rights treaties and norms create important standards for the United States federal and state governments to consider when regulating surrogacy. The United States is a party to a number of important United Nations human rights treaties. International human rights treaties and norms protect the rights of children, prohibit baby selling, and protect autonomy rights such as the right to reproductive autonomy, the right to work, and the right to found a family. By prohibiting surrogacy, the current New York law restricts the reproductive autonomy of surrogates and denies some parents the right to create a family. The CPSA would allow surrogacy while also protecting the rights of children.

\section{RECOMMENDATION}

The Child-Parent Security Act is an appropriate way to bring New York in line with the rest of the United States and other successful global surrogacy models while also providing appropriate protections for surrogates and children and complying with international human rights standards and norms. We also suggest additional protections and regulations that $\mathrm{New}$ York could adopt. 


\section{Methodology}

This report is the result of a collaboration between the Cornell Law School International Human Rights: Policy Advocacy Clinic (Cornell) and the Transnational Human Rights Seminar at the National Law University in Delhi, India (NLUDelhi). Under the supervision of faculty and teaching fellows, student research assistants investigated surrogacy from a variety of perspectives, particularly New York and India. Research assistants worked in five teams that each investigated a specific perspective on surrogacy: surrogacy in the United States, surrogacy in India, international human rights and surrogacy,

comparative law and surrogacy, and transnational surrogacy. Each team's work contributed to this report. The authors, along with research assistants, conducted desk and field research in the United States and India.

\section{DESK RESEARCH}

The NLU-Delhi and Cornell research teams conducted extensive desk research on surrogacy law and practice in the United States and across the world, including research on relevant international human rights law. The teams reviewed country-specific materials, including books and journals on surrogacy and surrogacy legislation. They also viewed articles and videos from the popular press to understand the range of perspectives on surrogacy. The research

assistants collected data on surrogacy law by state and by country, primarily using legislative sources where possible.

\section{INTERVIEWS WITH STAKEHOLDERS}

The authors developed detailed survey instruments for surrogates, intended parents, medical

professionals, and other actors. Participants were informed of the research goal- - to produce one report reviewing the CPSA and another reviewing the bill pending in India to ban compensated surrogacy. Surrogates were informed that their answers would be confidential and their real

names would not be identified in research reports without their permission. They were also told that taking part was voluntary. All survey instruments were approved by the Cornell University

Institutional Review Board.

In March 2017, Cornell research assistant conducted fieldwork in the United States, interviewing surrogacy lawyers who collectively have experience with surrogacy arrangements in New York, California, New Jersey, Florida, South Dakota, Idaho, Utah, Pennsylvania, Rhode Island, Delaware, and Oregon. Lawyers answered questions about their experience with and perspectives on the surrogacy industry in the state where they practiced. The Cornell research assistants also interviewed a doctor with surrogacy experience in the United States about the medical aspects of surrogacy. In April 2017, Cornell and

NLU-Delhi research assistants jointly conducted fieldwork in New Delhi, interviewing a variety of stakeholders in Indian surrogacy, including surrogates, fertility doctors, feminist scholars, non-profit organizations, and government officials.

\section{Glossary}

Compensated Surrogacy

Surrogacy in which the surrogate receives compensation for the reproductive care she provides beyond reimbursement for reasonable direct expenses. Also known as commercial surrogacy.

Embryo

Cells that form after fertilization of the eggs and sperm.

Gametes

Reproductive cells, specifically the eggs and sperm in humans.

Gestational Carrier

A woman who provides gestational care and give birth to a child for one or more intended parents in a gestational surrogacy arrangement.

Gestational Surrogacy

Surrogacy in which the egg(s) of the intended mother (or a predetermined female donor) that have been fertilized with sperm of the intended father (or a predetermined male donor) are used.

Intended Parent(s)

A single individual or couple who contract for a third party to give gestational care to and give birth to a child for them.

Matching Entity

An organization that helps to coordinate

arrangements between intended parent(s) and a surrogate.

Surrogacy

A process through which one or more intended parents contract for a third party -a surrogate- to provide gestational care for and give birth to a child for them.
Surrogate or Surrogate Mother

A woman who provides gestational care and gives birth to a child for one or more intended parents.

Traditional Surrogacy or Genetic Surrogacy

Surrogacy in which the surrogate's own egg(s) and the sperm of the intended father (or a

predetermined male donor) are used.

Uncompensated Surrogacy

Surrogacy in which the surrogate only receives compensation for reasonable direct expenses. Also known as altruistic surrogacy. 


\section{CHAPTER 1}

\section{The Surrogacy Process}

Surrogacy is a process through which couples or single adults (known as intended parents) contract with a third party—a surrogate— to provide gestational care for and to give birth to a child for them. The process is important, as it enables single adults and couples who were previously unable to have children, including infertile and male samesex couples, to become parents. The genetic relationship between the child and the intended parents, and the child and the surrogate depends on the type of surrogacy. There are two types of surrogacy arrangements:

\section{- Traditional Surrogacy or}

Genetic Surrogacy

In traditional surrogacy, the surrogate's own egg(s) and the sperm of the intended father (or a predetermined male donor) are used. ${ }^{1}$

Traditional surrogacy typically involves artificia insemination of the surrogate. Because this process uses the surrogate's egg(s), it creates a biological relationship between the surrogate and the child.
- Gestational surrogacy

Gestational surrogacy involves implanting embryos created with the egg(s) of the intended mother (or a predetermined female donor) that have been fertilized with sperm of the intended father (or a predetermined male donor). ${ }^{2}$ This is done using in vitro fertilization (IVF) technolog/ which was first successfully tested in $1978 .^{3}$ During IVF, mature eggs are collected from the ovaries of a woman and fertilized by sperm in lab. The fertilized egg(s) (or embryo(s)) are transferred into the surrogate's uterus.

In gestational surrogacy, eggs are collected from the intended mother (or a predetermined female donor) and are then fertilized with sperm from the intended father (or a predetermined male donor). The embryos are then grown and implanted into the uterus of the surrogate. ${ }^{4}$ Gestational surrogacy accounts for around ninety-five percent of all surrogacies in the United States. ${ }^{5}$ A surrogate whose eggs are not used in the surrogacy

arrangement is often referred to as a "gestational carrier."

\section{THE GESTATIONAL SURROGACY PROCESS}

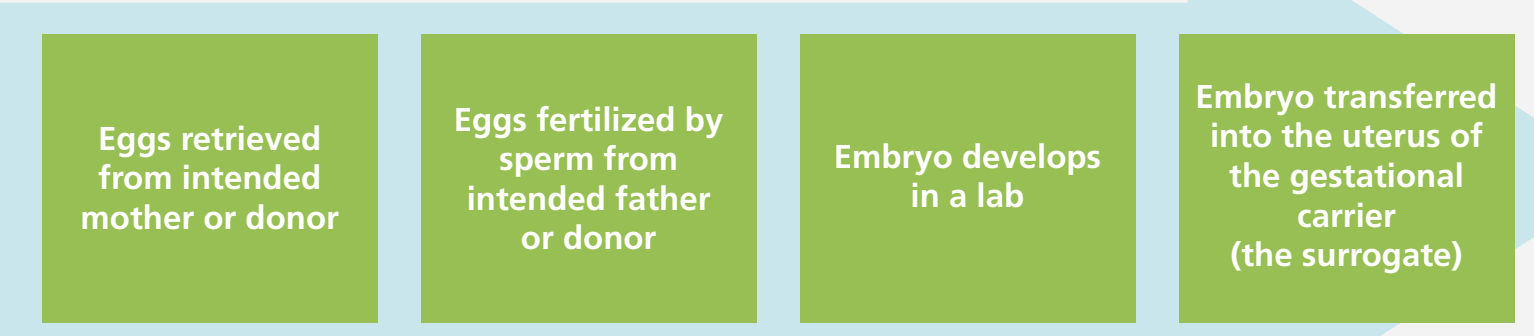

A surrogacy arrangement is an agreement between intended parents and a surrogate that the surrogate will carry a child to term and will relinquish parental rights to the intended parents. A surrogacy arrangement also typically involves intermediaries such as matching entities (who coordinate surrogacy arrangements and match surrogates with intended parents), medical practitioners (who perform medical procedures and provide medical advice), and lawyers (who provide legal advice and other legal services relating to surrogacy agreements).

\section{KEY PARTICIPANTS IN \\ A SURROGACY AGREEMENT}

The Intended Parent(s) contract with a third party to carry a baby for them.

The Surrogate carries and gives birth to a child created through assisted

reproduction, for the intended parents.

A Gestational Carrier is a surrogate whose egg(s) are not used in the surrogacy arrangement.

Matching Entities coordinate arrangements between the intended parents and the surrogate.

Medical Practitioners perform the assisted reproductive procedures (e.g., the IVF) and monitor the pregnancy of the surrogate.

Surrogacy agreements can be uncompensated (altruistic) - the surrogate receives only reimbursement for reasonable, direct expenses-or compensated (commercial) - the surrogate receives compensation for the reproductive care she provides beyond reimbursement for reasonable direct expenses. 
CHAPTER 2

The Past, Present, and Future of Surrogacy Law in New York

A. ORIGINS OF NEW YORK'S PROHIBITION ON SURROGACY

THE MATTER OF BABY M, 537 A.2D 1227 (N.J. 1988)

Mary Beth Whitehead conceived and gave birth to Baby $M$ who was her genetic child and also the genetic child of William Stern. The surrogacy contract provided Stern. The surrogacy contract provided
that the surrogate mother (Mary Beth Whitehead) would be inseminated with Whitehead) would be inseminated with
the sperm of the intended father (William the sperm of the intended father (William the surrogate mother would relinquish parental rights and give the child to William Stern. However, after Baby M was born Mary Beth Whitehead changed her mind and wanted to keep the child. Eventually the case reached the New Jersey Supreme Court and in a precedential decision, it decided that surrogacy contracts were invalid because they violated public policy and state adoption laws. Without a surrogacy contract to decide custody of the child the Court then used the default family law rules (namely, the "best interest of the child" test) to give William Stern custody of Baby $\mathrm{M}$, but only visitation rights to Mary Beth Whitehead.

The New York State Legislature prohibited compensated surrogacy in 1992 on the heels of a case that garnered national media attentionthe Matter of Baby M. ${ }^{6}$ Baby $M$ was a catalyst for many lawmakers to urge legislative regulation of surrogacy. Some called for criminalizing surrogacy, while others sought appropriate regulation.?
While most legislatures, including the New Jersey legislature, never adopted bans, New York banned compensated surrogacy based on the strong recommendations of a 1988 report by the New York Task Force for Life and the Law. ${ }^{8}$ The Task Force concluded that public policy should discourage surrogate parenting. In justifying this conclusion, they argued that surrogacy" places children at risk and is not in their best interests or those of society at large," "has the potential to undermine the dignity of women, children, and human reproduction by commercializing childbearing," and"represents a significant departure from existing values and standards about parental rights and responsibilities embodied in New York State law.." ${ }^{\prime \prime}$ On the basis of these conclusions and the idea that a legislature "should act to safeguard the basic values and rights that have long been embodied in our laws on the relationship between parents and their children," ${ }^{10}$ the Task Force proposed legislation that formed the motivation for, and substantially provided

the language which comprises, the current New York law on surrogacy—-the New York Domestic Relations Law Article 8. ${ }^{11}$

B. DESCRIPTION OF NEW YORK SURROGACY LAW

In New York, uncompensated and compensated surrogacy agreements are both void and unenforceable. Furthermore, those entering into, or assisting others in entering into, compensated surrogacy agreements are subject to fines and criminal sanctions. ${ }^{12} \mathrm{~A}$ penalty of $\$ 500$ attaches to the conduct of intended parents and surrogates (along with their spouses) participating in a surrogacy arrangement in which payment exceeds reasonable medical expenses and those expenses permissible in an adoption. ${ }^{13}$ Any other person or entity who induces, arranges or otherwise assists in the formation of a surrogacy agreement in violation of statutory restrictions may face fines up to $\$ 10,000$ and forfeiture of any fees received, and shall be guilty of a felony if they have been previously subject to a civil fine for violating the section. ${ }^{14}$
CURRENT NEW YORK LAW: KEY PROVISIONS

All surrogacy contracts (including compensated and uncompensated surrogacy) are void and orceable.

- Civil fine of $\$ 500$ for participating in compensated surrogacy arrangement.

- Any person who assists in the formation of a compensated surrogacy arrangement may face fines of up to $\$ 10,000$ and forfeiture of any fees received.

Any person who assists in the formation of a compensated surrogacy arrangement having already been subject to the civil fine is guilty of a felony.

While the parties to an uncompensated surrogacy arrangement are not subject to fines or criminal sanctions, the surrogate is considered under New York law to be the presumptive legal mother of the child. ${ }^{15}$ Consequently, if a child is born through a surrogacy arrangement in New York, the child's legal relationship to his or her intended parents is insecure.

In addition, because surrogacy agreements are void and unenforceable, a surrogate cannot sue to recover any payments due to her. A New York appellate court has even refused to enforce a contract to perform IVF services against a physician who agreed to transfer an embryo in connection with a paid surrogacy. ${ }^{16}$ Stating that the IVF services were"part and parcel of [the surrogacy] contract," the court declined to enforce the contract because"a party to an illegal contract cannot seek a court of law to help her carry out her illegal object, and the court will leave the parties to such a contract where they find them."117
THE CHILD-PARENT SECURITY ACT: KEY PROVISIONS

- Compensated gestational surrogacy agreements are legally enforceable provided they meet certain criteria. The CPSA does not apply to traditional surrogacy.

Payment must be reasonable and negotiated in good faith and cannot be dependent on qualities or characteristics of gametes or the resulting child.

Pre-birth orders (recognizing the intended parents as legal parents) can be obtained by intended parents and become effective upon birth.

- Surrogate must agree to relinquish child upon birth, and intended parents must agree to accept custody of and responsibility for the child.

- Surrogate retains the right to terminate the pregnancy and make decisions related to her health and the health of the fetus during pregnancy.

Surrogate must be at least twenty-one years old, have completed a medical evaluation, have undergone legal consultation with independent counsel of their choosing, and have an appropriate health insurance policy.

Despite the fact that uncompensated surrogacy agreements are unenforceable, they still occur in New York. The parties typically execute a "memorandum of understanding," which, though unenforceable, helps the parties understand each other's positions on important issues such as abortion and selective reduction. ${ }^{18}$ 
C. PROPOSED CHANGES TO NEW YORK SURROGACY LAW: THE CHILD-PARENT SECURITY ACT

A version of the Child-Parent Security Act of 2017 (the CPSA) was first introduced in 2012 by

Assembly Member Amy Paulin (D-Scarsdale) and was introduced in the Senate by Senator Brad Hoylman (D-Manhattan, 27th District). It is a comprehensive bill addressing the parentage of al children born through third-party reproduction, but we focus specifically on aspects of the CPSA that address surrogacy in this report. The CPSA permits New York residents to enter into enforceable, compensated gestational surrogacy agreements, as long as the agreements comply with several criteria, and provides mechanisms for establishing the legal parentage of children conceived with assisted reproductive technology.

Some of the key provisions of the CPSA are noted below:

Recognition of Compensated Gestational Surrogacy Agreements Only

The CPSA states that if intended parents, a gestational carrier, and the gestational carrier's spouse (if applicable) enter into a gestational surrogacy agreement, this agreement will be enforceable provided that it meets certain requirements. ${ }^{19}$ Note that only gestational surrogacy agreements, not traditional surrogacy agreements, would be enforceable under the CPSA. Under the proposed bill, a gestational surrogacy agreement may provide reasonable compensation negotiated in good faith. ${ }^{20}$

Compensation must be placed in escrow (with an independent escrow agent) before the gestational carrier undergoes any medical procedures, ${ }^{21}$ and can be based on services rendered, expenses, and/ or medical risks that have been or will be incurred time, and inconvenience..$^{22}$ Importantly, compensation cannot be conditioned on the quality of genome-related traits of gametes or embryos, actual genotypic or phenotypic characteristics of the donor or the child, or the health or condition of the child ${ }^{23}$
Terms that Must Be Included in Surrogacy Agreements

The surrogacy contract must include an agreemen by the gestational carrier (and the carrier's spouse, if any) for the surrogate to undergo embryo transfer and to attempt to carry and give birth to the child(ren), and to surrender custody of resulting child(ren) to the intended parent(s) immediately after the birth. ${ }^{24}$ The intended parent(s) must agree to accept custody of the resulting child(ren) immediately upon birth regardless of number, gender, and/or mental or physical condition, and must agree to assume sole responsibility for the resulting child(ren). ${ }^{25}$

\section{Judgment of Parentage}

The CPSA legally establishes a child's relationship to his or her parents where the child is conceived through collaborative reproduction. ${ }^{26}$ Under the CPSA, when an intended parent (or donor acting on behalf of the intended parent) provides eggs for assisted reproduction, the intended parent will be considered the legal parent of the resulting child for all purposes. ${ }^{27}$ When an intended parent (or a donor acting on behalf of the intended parent) provides the sperm for the assisted reproduction, the intended parent will be considered the legal parent for all purposes. Importantly, the bill states that the court shall issue a judgment of parentage (a court order that confirms legal parentage) to the intended parents in a valid surrogacy agreement. ${ }^{28}$ This can be obtained prior to the birth of the child although it will only become effective upon birth. ${ }^{29}$

The Rights of the Surrogate

Under the bill, a surrogacy agreement cannot limit the right of a surrogate to make decisions safeguarding her own health or that of a fetus or embryo she is carrying. ${ }^{30}$ The agreement also cannot limit the right of the surrogate to terminate a pregnancy or reduce the number of fetuses she is carrying, ${ }^{31}$ or the right of the surrogate to use a health care provider of her own choosing. ${ }^{32}$ In addition, the surrogate (or her husband) or any intended parent may terminate the surrogacy greement by giving notice of termination prior to the surrogate becoming pregnant, and will be released from all obligations under the agreement. $^{33}$

Requirements to Be a Surrogate

Under the bill, surrogates must be at least twentyone years old, must not have contributed the egg from which the embryo was formed, must have completed a medical evaluation relating to the planned pregnancy, and must have undergone a legal consultation with independent legal counse of her choosing (and also her spouse if applicable) ${ }^{34}$ The surrogate must also have (or be required to obtain prior to embryo transfer) a health insurance policy covering major medical treatments and hospitalizations, and this must extend through the pregnancy and for eight weeks after the birth of the child. This health insurance policy may be procured and paid for by the intended parents, pursuant to the surrogacy contract. $^{35}$ 


\section{CHAPTER 3}

\section{New York Law is an Outlier in the United States Today}

Surrogacy is flourishing across the United States. ${ }^{36}$ Indeed, California is one of the world's

destinations for surrogacy. ${ }^{37}$ As discussed below, New York is one of only two states in the country with the most restrictive surrogacy laws. Many states explicitly permit surrogacy by legislation. Other states have not adopted legislation to permit or prohibit it, and in those states surrogacy is still practiced. As such, the current New York law is not in line with the rest of the country. Because of the prohibition in New York and the permissive laws and policies in other states, New York residents often enter into surrogacy arrangements out-ofstate and consequently face numerous legal, financial and practical challenges. Adopting the CPSA would bring New York in line with the rest of the country and provide important protections for New Yorkers.

\section{A. COMPARING NEW YORK LAW TO} SURROGACY LAWS IN OTHER STATES

Surrogacy is largely regulated by state law. States have adopted many different approaches. Some states explicitly permit and regulate one or both types of surrogacy arrangements (compensated and uncompensated) either through legislation or case law.

Other states explicitly prohibit one or both types of surrogacy arrangements (compensated and uncompensated) either through legislation or by case law. Some states that prohibit surrogacy simply declare that surrogacy contracts are not enforceable by courts. Accordingly, if there are disputes between the parties or one party desires not to abide by the contract terms, the parties have no recourse to the courts. Other states additionally impose fines and/or criminal sanctions on one or more participants in the surrogacy arrangements.

In the remaining states, there is no legislation or case law that directly addresses surrogacy. In those states, surrogacy is practiced and the parentage of the child, disputes, and other issues that arise are governed by family law or other existing laws in those states.

We divide the states into four categories: (1) states that explicitly permit both compensated and uncompensated surrogacy either through legislation or case law and states that have no legislation or authoritative case law prohibiting surrogacy ("Category 1 States"), (2) states that explicitly permit uncompensated surrogacy (either by legislation or case law) or do not prohibit it, but do not allow compensated surrogacy (by either refusing to enforce surrogacy contracts and/or criminally sanctioning people involved in the surrogacy process) ("Category 2 States"), (3) states that do not allow both uncompensated surrogacy and compensated surrogacy (by refusing to enforce all surrogacy contracts) ("Category 3 States"), and (4) states that do not allow both uncompensated surrogacy and compensated surrogacy (by refusing to enforce all surrogacy contracts and imposing criminal sanctions) ("Category 4 States"). Table 1 shows the states in each category.

The significant majority of the states in the country are Category 1 States, which means they have a

permissive approach to surrogacy. Even in many of the Category 2 States that purport to permit only uncompensated surrogacy, surrogacy

arrangements in which the surrogate is paid still flourish in practice. In Category 2 States, intended parents can pay surrogates "reasonable expenses" such as medical expenses or living expenses.

Anecdotal evidence suggests that sometimes the parties to the surrogacy contract in those states inflate the living costs so that the surrogates do receive compensation for the reproductive care they are providing.

In many Category 2 states, surrogacy is widely practiced. For example, in Nebraska, although compensated surrogacy contracts are unenforceable, uncompensated surrogacy is permitted. This permissive approach to uncompensated surrogacy combined with a law making the biological father (and not the surrogate) the sole legal parent of a child born through a surrogacy arrangement, ${ }^{38}$ creates a favorable legal environment for surrogacy arrangements. In Nebraska, the biological father of the child is considered its sole parent and the surrogate is not considered the legal parent. Consequently, surrogacy arrangements are regularly undertaken in Nebraska. ${ }^{39}$

Even in Category 3 States, where both compensated and uncompensated surrogacy agreements are unenforceable but not criminally sanctioned, surrogacy is sometimes practiced. For example, although an Arizona statute prohibits a person from entering into or assisting in creating a surrogacy contract, ${ }^{40}$ surrogacy is still practiced. ${ }^{41}$ Intended parents and surrogates enter into documents that they understand are not enforceable in court. Attorneys even provide advice on these non-binding documents. Although the surrogate is deemed to be the legal parent of the child, Arizona law allows intended parents to rebut that presumption. ${ }^{42}$ Courts regularly grant prebirth orders declaring the intended parents (and not the surrogate) the legal parents..$^{43}$ Unlike New York, Arizona does not impose criminal sanctions on the intended parents, surrogate, attorneys, medical professionals or any other party who participates in the process.
To the extent that there is a legislative trend, it is toward legalizing surrogacy where it is illegat or providing a statutory framework where the surrogacy industry operates with little regulation. For example, Washington D.C. recently adopted a new law that took effect on April 7, 2017, that explicitly recognizes compensated surrogacy contracts and codifies best practices. ${ }^{45}$

New York and Michigan are the only two states in the country where uncompensated or compensated surrogacy agreements are not enforced and where parties to compensated surrogacy agreements are subject to criminal sanctions. Because of the criminal sanctions, potential parties to a surrogacy arrangement and intermediaries in New York are reluctant to explore even out of state surrogacy for fear of criminal sanctions. Like New York's ban, Michigan's ban was adopted decades ago in 1988. ${ }^{46}$ New York remains an outlier with the rest of the country in terms of its restrictive surrogacy laws. 


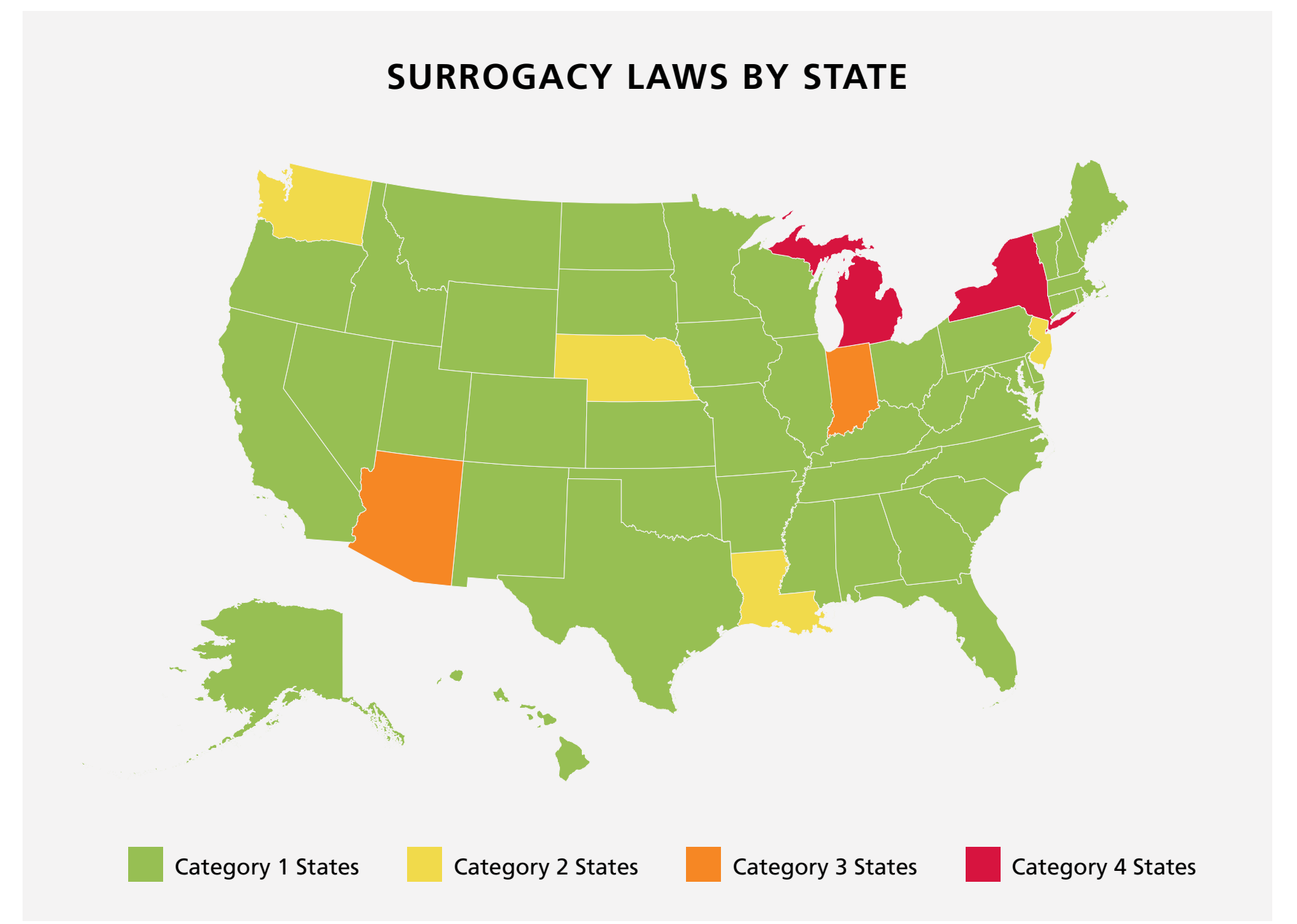

Figure 2: Surrogacy Laws by State

TABLE 1: SURROGACY LAWS BY STATE ${ }^{47}$

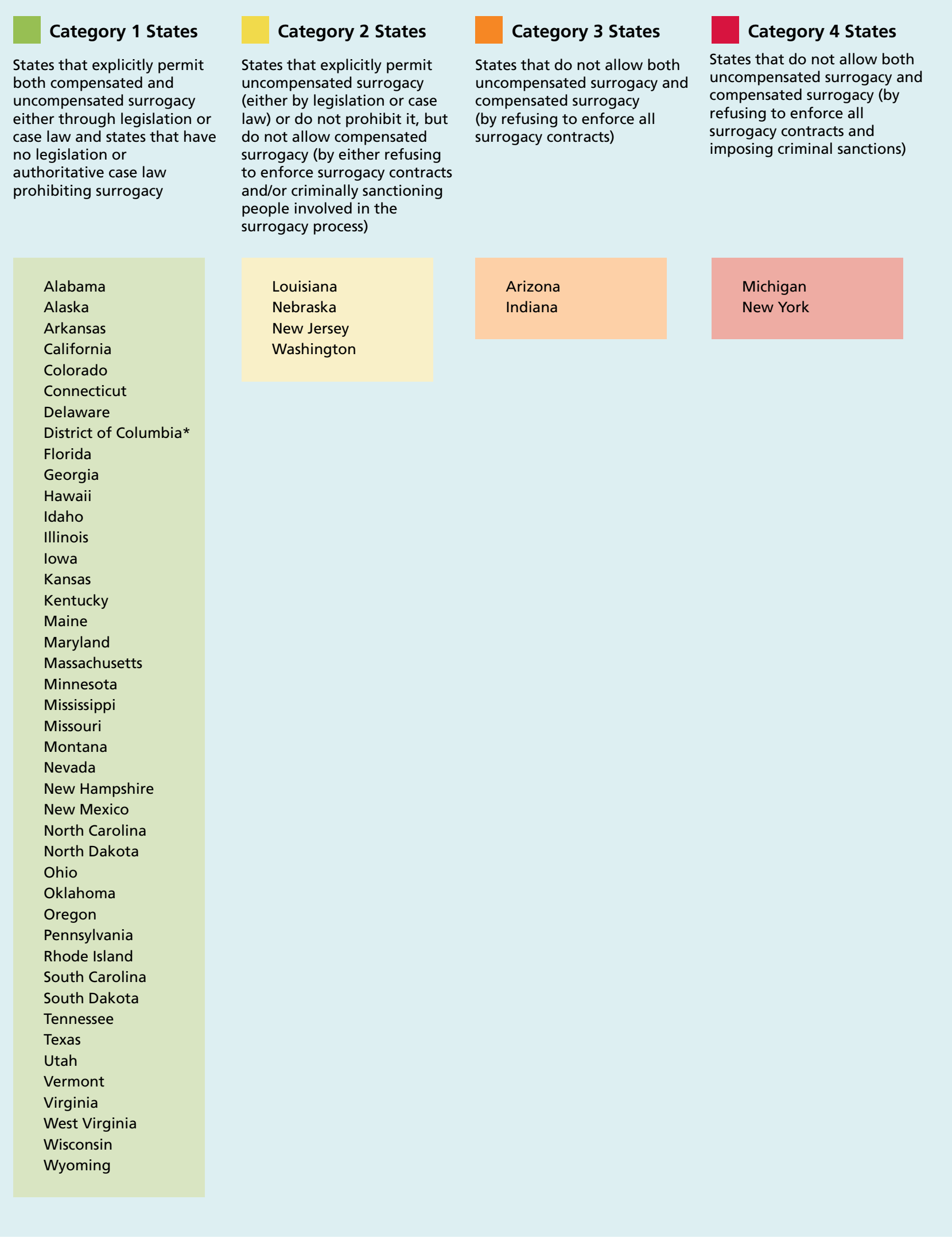

*District of Columbia is included in this Table even though it is not a state. 
B. NEW YORKERS ARE

DISADVANTAGED BECAUSE THEY

HAVE TO ENGAGE SURROGATES OUTOF-STATE

Infertile and same-sex couples and single adults from New York who want to enter into a surrogacy agreement and can afford it, hire surrogates in states where surrogacy is permitted. ${ }^{48}$ When New Yorkers contract with surrogates in other states, their contracts usually contain choice-of-law clauses specifying that the law of the foreign state governs the contract and the child is born in that state. ${ }^{49}$ Since the child's place of birth is one place where a potential custody battle can arise, surrogacy contracts may require surrogates to give birth in states that enforce surrogacy contacts 50

Before or after the surrogate successfully delivers a child in a surrogacy-friendly state, the intended parents typically obtain an order of parentage pursuant to the law of that state.

Even though New Yorkers regularly structure out of-state surrogacy arrangements to enhance lega certainty, they still face several challenges and risks. First, there is a risk that New York law could still be applied to the arrangement, meaning that it would not be enforceable and leading to uncertainty over parentage of the child(ren). A basis for jurisdiction over a surrogacy agreement will exist in New York where there is a significant nexus to New York even where the agreement states that a different state's law should govern. For example, if an embryo transfer occurred in New York, a New York court could assert jurisdiction. Second, conducting a surrogacy arrangement out of state can lead to legal uncertainty as to which states' laws ultimately govern the parentage of the child(ren) even where there is no nexus to New York. For example where there is a nexus to two other states. ${ }^{51}$ Again, this can lead to uncertainty over parentage of the

child(ren). Third, out-of-state surrogates are not accountable to intended parents in New York and New Yorkers are left having to conduct any litigation in another jurisdiction. Fourth, even where a surrogacy takes place out of state, New
Yorkers can end up having to engage in litigation to adopt their child in New York. For example intended parents from New York might contract with a surrogate in another state or country who gives birth in that state or country, but that state or country does not recognize one of the intended parents on the child's birth certificate. One situation where this can occur is where the surrogate gives birth in a jurisdiction that will not list a person who is not genetically related to a child on the child's birth certificate and a donor or donors have been used so one or both of the

intended parents are not genetically related to the child. ${ }^{52}$ Fifth, New Yorkers who enter into surrogacy contracts out-of-state also incur greater expenses in carrying out a surrogacy agreement because of travel costs throughout the pregnancy. Finally, many couples that ultimately choose surrogacy as a method to procreate do so after spending significant time working with their fertility doctors and clinics. When they realize that other medical options have failed, they may have to switch to a provider outside of New York, disrupting the continuity of care and the relationships that they have formed with their medical providers. Thus, even though surrogacy is not permitted in New York, New Yorkers enter into surrogacy arrangements in other states, but this can lead to uncertainty over the parentage of the child(ren) and disadvantages New Yorkers both legally and financially.

C. COMPARING THE CPSA TO SURROGACY LAWS IN OTHER STATES Adopting the CPSA would bring New York surrogacy law in line with the majority of states that expressly permit and regulate surrogacy. Table 2 below compares key provisions of the CPSA to surrogacy laws in five states in which surrogacy is legalized and regulated by statute-California, Delaware, Illinois, Nevada, and New Hampshire. Our analysis suggests that the regulations in the CPSA, including the protections offered to the parties involved in surrogacy, are generally consistent with the laws in other states where compensated surrogacy is permitted and regulated.
TABLE 2: COMPARISON OF CPSA TO SURROGACY LAWS IN SEVERAL OTHER STATES

\begin{tabular}{|c|c|c|c|c|c|c|}
\hline & CPSA & CALIFORNIA & DELAWARE & ILLINOIS & NEVADA & $\begin{array}{l}\text { NEW } \\
\text { HAMPSHIRE }\end{array}$ \\
\hline $\begin{array}{l}\text { Type of } \\
\text { surrogacy } \\
\text { allowed by } \\
\text { statute: }\end{array}$ & $\begin{array}{l}\text { Gestational } \\
\text { only }\end{array}$ & $\begin{array}{l}\text { Gestational } \\
\text { only }\end{array}$ & $\begin{array}{l}\text { Gestational } \\
\text { only }\end{array}$ & $\begin{array}{l}\text { Gestational } \\
\text { only }\end{array}$ & $\begin{array}{l}\text { Gestational } \\
\text { only }\end{array}$ & $\begin{array}{l}\text { Gestational } \\
\text { only }\end{array}$ \\
\hline $\begin{array}{l}\text { Restrictions } \\
\text { on payment }\end{array}$ & $\begin{array}{l}\text { Consideration } \\
\text { must be reason- } \\
\text { able and negotiat- } \\
\text { ed in ingood faith } \\
\text { and must be } \\
\text { placed in escrow } \\
\text { before any } \\
\text { procedures take } \\
\text { place. Compensa- } \\
\text { tion can cover } \\
\text { reimbursement for } \\
\text { economic losses } \\
\text { and insurance } \\
\text { premiums, services } \\
\text { rendered, } \\
\text { expenses that have } \\
\text { or will be incurred, } \\
\text { time, and } \\
\text { inconvenience. } \\
\text { Consideration may } \\
\text { not be paid to } \\
\text { purchase gametes } \\
\text { or embrysos, or to } \\
\text { pay for the } \\
\text { relinquishment of } \\
\text { a parantal interest } \\
\text { in a child. lo the } \\
\text { Payments to the } \\
\text { surrogate shall not } \\
\text { exceed the } \\
\text { duration of the } \\
\text { pregnancy and up } \\
\text { to eight weeks } \\
\text { after the birth of } \\
\text { the child. }\end{array}$ & - & $\begin{array}{l}\text { Consideration } \\
\text { must be } \\
\text { reasonable. } \\
\text { Reasonable } \\
\text { expenses may be } \\
\text { covered. Funds } \\
\text { must be placed } \\
\text { in escrow before } \\
\text { an embryo } \\
\text { transfer occurs. }\end{array}$ & $\begin{array}{l}\text { Compensation } \\
\text { must be } \\
\text { reasonable. }\end{array}$ & $\begin{array}{l}\text { Ban on } \\
\text { payment for } \\
\text { genotypic or } \\
\text { phenotypic } \\
\text { characteristics. } \\
\text { Reasonable } \\
\text { expenses may } \\
\text { be covered. }\end{array}$ & $\begin{array}{l}\text { Compensation } \\
\text { must be } \\
\text { reasonable. } \\
\text { This can } \\
\text { include, but is } \\
\text { not limited to, } \\
\text { payment of the } \\
\text { surrogate's } \\
\text { reasonable } \\
\text { medical, } \\
\text { counseling, } \\
\text { legal, and/or } \\
\text { other expenses. }\end{array}$ \\
\hline
\end{tabular}




\section{TABLE 2 CONTINUED}

\begin{tabular}{|c|c|c|c|c|c|c|}
\hline & CPSA & CALIFORNIA & DELAWARE & ILLINOIS & NEVADA & $\begin{array}{l}\text { NEW } \\
\text { HAMPSHIRE }\end{array}$ \\
\hline $\begin{array}{l}\text { Requirements } \\
\text { for surrogates }\end{array}$ & $\begin{array}{l}\text { Must be at least } \\
21 \text { i must tundergo } \\
\text { medical examina- } \\
\text { tion; must have or } \\
\text { will obtain prior to } \\
\text { embryo transfer, a } \\
\text { health insurance } \\
\text { policy that covers } \\
\text { major medical } \\
\text { treatments and } \\
\text { hospitalization } \\
\text { that extends } \\
\text { throughout the } \\
\text { intended pregnan- } \\
\text { cy and for } 8 \text { weeks } \\
\text { atter the birth of } \\
\text { the child (this may } \\
\text { be procured and } \\
\text { paid for by the } \\
\text { intended parents). }\end{array}$ & - & $\begin{array}{l}\text { Must be at least } \\
21 ; \text { must have } \\
\text { given birth to at } \\
\text { least one child; } \\
\text { must undergo a } \\
\text { medical and } \\
\text { mental health } \\
\text { examination; } \\
\text { must have a } \\
\text { health insurance } \\
\text { policy that covers } \\
\text { major medical } \\
\text { treatments and } \\
\text { hospitaliazition } \\
\text { and lasts at least } \\
8 \text { weeks after } \\
\text { due date (this } \\
\text { may be covered } \\
\text { by the intended } \\
\text { parents). }\end{array}$ & $\begin{array}{l}\text { Must be at least } \\
21 ; \text { must have } \\
\text { given birth to at } \\
\text { least one child, } \\
\text { must have } \\
\text { completed a } \\
\text { mental health } \\
\text { evaluation, } \\
\text { must have } \\
\text { health } \\
\text { insurance policy } \\
\text { that covers } \\
\text { major medical } \\
\text { treatments and } \\
\text { hospitalization } \\
\text { and lasts at } \\
\text { least } 8 \text { weeks } \\
\text { after the due } \\
\text { date (this may } \\
\text { be covered by } \\
\text { the intended } \\
\text { parents). }\end{array}$ & - & $\begin{array}{l}\text { Must be at } \\
\text { least } 21 \text {; must } \\
\text { have given } \\
\text { birth to at least } \\
\text { one child, must } \\
\text { undergo } \\
\text { medical } \\
\text { examination, } \\
\text { must have } \\
\text { mental health } \\
\text { consultation. }\end{array}$ \\
\hline $\begin{array}{l}\text { Independent } \\
\text { counsel } \\
\text { required for } \\
\text { all parties }\end{array}$ & Yes & Yes & Yes & Yes & Yes & Yes \\
\hline $\begin{array}{l}\text { Prebirth } \\
\text { orders } \\
\text { granted }\end{array}$ & Yes & Yes & Yes & No & Yes & Yes \\
\hline $\begin{array}{l}\text { Requirement } \\
\text { for intended } \\
\text { parents to } \\
\text { accept legal } \\
\text { custody and } \\
\text { responsibility } \\
\text { upon birth }\end{array}$ & Yes & 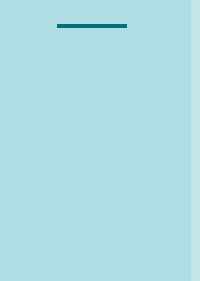 & Yes & Yes & Yes & Yes \\
\hline
\end{tabular}

Adopting the CPSA would bring New York law in line with most other states in the United States that explicitly allow and regulate compensated surrogacy. The CPSA would also provide statutory protections to all parties and certainty regarding the parentage of children, and if it were adopted, New Yorkers would not continue to be legally and financially disadvantaged by having to enter into surrogacy arrangements out of state. The CPSA is also consistent with other states because it

recognizes only gestational surrogacy, allows prebirth orders, requires independent counsel for all parties, requires compensation to be reasonable, and requires intended parents to accept legal custody and responsibility upon birth regardless of the health of the child. 


\section{CHAPTER 4}

\section{Decreasing Relevance of the Concerns that Led to the New York Ban}

The report published by the New York Task Force on Life and the Law (the Task Force) in 1988

heavily influenced New York to ban surrogacy. After describing arguments both for and against surrogacy, the report recommended

a ban on surrogacy. ${ }^{53}$ The Task Force raised five main concerns: (i) individual access and societal responsibility in the face of new technological possibilities; (ii) the interests of children; (iii) surrogacy's impact on family life and relationships, (iv) individual liberty in human reproduction and attitudes about reproduction and women; and (v) application of the informed-consent doctrine.

Many of the Task Force report's concerns have been alleviated by technological and/or societal changes. Other concerns about surrogacy's potential

consequences have not materialized in other states where surrogacy is widely practiced. Of the points raised by the Task Force that are still salient, many of them are addressed by the CPSA. Consequently, many of the arguments articulated by the Task Force nearly thirty years ago should no longer carry significant weight in the debate about surrogacy today.

\section{A. CONCERNS RELATING TO NEW} TECHNOLOGY ARE LESS RELEVANT

The Task Force's first concern involved individual access and societal responsibility in the face of new technological possibilities. The Task Force noted that opponents of surrogacy argue that surrogacy involves new technology and that, until it is demonstrated that the practice is not harmful, it should not be allowed. ${ }^{54}$ The technology used for surrogacy, IVF, is no longer new technology, but has been legally available in New York for decades. ${ }^{55}$ Egg donation and sperm donation are also legal. In a report issued ten years after the report on surrogate parenting, the Task Force called for regulation rather than prohibition of assisted reproduction. ${ }^{56}$ Thus, even the Task Force has largely accepted and recognized that most of the major technological components of surrogacy should not be illegal, but should be legal and regulated.

B. CONCERNS RELATING TO THE INTERESTS OF CHILDREN HAVE LARGELY NOT BEEN BORNE OUT BY SURROGACY PRACTICE

The Task Force's second set of concerns involved the children born from surrogacy agreements. First, the Task Force referred to concerns that surrogacy constitutes baby selling. ${ }^{57}$ When the Task Force Report was published, the few surrogacy arrangements that existed were" traditional surrogacy" arrangements, ${ }^{58}$ but today most involve gestational surrogacy. Indeed, the CPSA only permits enforcement of gestational surrogacy agreements. This means that the surrogate is not carrying a child created from her egg. In addition, legal innovations by courts grant parenthood rights to the intended parents prior to the birth of the child: indeed, the CPSA specifically permit pre-birth orders. Under the CPSA, when the intended parents provide gametes (either their own or donated to them by others) for assisted reproduction in order to be the parent of the resulting child and the surrogate consents, the intended parent is the parent of the child for all legal purposes. ${ }^{59}$ Thus, concerns that the surrogate is selling her child are alleviated by the fact that the surrogate is not a genetic parent and the intended parents and not the surrogate have legal responsibility for the child at birth. Further, any compensation is specifically characterized as payment for time, effort, pain and/or risk to heath in excess of reasonable medical and ancillary costs. ${ }^{60}$ Put simply, the surrogate is selling a service, and not a child.
Second, the Task Force noted that the identity and emotional well-being of a child delivered by a surrogate could be harmed because surrogacy arrangements fracture parenting into genetic, gestational, and rearing components. ${ }^{61}$ The Task Force also noted that other children could be harmed through surrogacy arrangements, including the surrogate's pre-existing children who may develop fears of abandonment and sadness from having lost a sibling. ${ }^{62}$ While numerous fears about children's well-being existed decades ago and some still make those arguments, empirical research has not substantiated these concerns. In fact, research suggests that surrogacy does not have a negative effect (and may have a positive effect) on children born of surrogacy

arrangements ${ }^{63}$ and the existing children of surrogates. ${ }^{6}$

Third, the Task Force pointed out that intended parents might abandon disabled children. ${ }^{65}$

Although this is not a widespread problem, there have been cases where disabled children have been abandoned by their intended parents. In one case, when a fetus was diagnosed with Down syndrome, the intended parents told the surrogate to abort the fetus. When the surrogate refused, the intended parents relinquished any claim to the child. The surrogate nonetheless gave birth to the child, and she and her partner took custody of and assumed responsibility for the child. ${ }^{66}$ While any parent, regardless of how the child was conceived, could choose to relinquish their child due to the child's disability, surrogacy laws must proactively address this risk. Under the CPSA, the intended parents are legally obligated to accept custody of the child(ren) immediately upon birth regardless of number, gender, or mental or physical condition and agree to assume sole responsibility for the resulting child(ren) ${ }^{67}$ Surrogacy lawyers that we interviewed also suggested that it is good practice to discuss issues such as disability and abortion with intended parents and surrogates prior to the surrogacy, to ensure that both parties are in agreement about what should occur if the fetus is diagnosed with disabilities.
C. CONCERNS REGARDING SURROGACY'S IMPACT ON FAMILY LIFE AND RELATIONSHIPS ARE LESS RELEVANT

The Task Force articulated a set of concerns relating to how surrogacy disrupts traditional notions of family ${ }^{69}$ The arguments centered around the assumption that surrogacy involved a heterosexual married couple where the child was the biological child of the man of the couple and of the female surrogate. For example, the Task Force noted that surrogate parenting violates the traditional relationship of parents and children by promoting the abdication of the parental responsibility to nurture one's children (presumably by the surrogate). The Task Force further noted that the fact that the child is genetically linked to only one parent could weaken the bond between the unrelated parent and the child. ${ }^{70}$ However, as noted above, today surrogacy arrangements are largely gestational and the CPSA would only allow enforcement of those arrangements.

Additionally, the traditional model of a family as one male and one female married couple has greatly evolved since the report was published nearly thirty years ago. A growing number of couples are same-sex partners. Obviously for same-sex couples, only one parent (at most) will be genetically connected to the child. The U.S Supreme Court's decision in 2015 to guarantee same-sex couples equal marriage rights evidences changing social norms and beliefs. ${ }^{71}$ While it is true that surrogacy has the potential to change traditional notions of family by creating new possibilities for parental relationships, what are considered acceptable family structures by our society has already changed. Thus, the concerns articulated by the Task Force in this regard are less relevant today. 
D. CONCERNS REGARDING INDIVIDUAL LIBERTY IN HUMAN REPRODUCTION AND ATTITUDES ABOUT

REPRODUCTION CAN BE ADDRESSED THROUGH REGULATION

Another set of concerns raised by the Task Force relate to women in their role as surrogates. The Task Force cites several authors that view surrogacy as problematic because it involves the buying and selling of gestational care. Some authors are not troubled by surrogacy that does not involve

compensation for gestational care, but other author oppose even uncompensated surrogacy. Other sets of concerns relate to the idea that surrogacy constrains a women's reproductive right to terminate her pregnancy. ${ }^{72}$

Legalizing surrogacy and including a strong set of protections for surrogates in legislation addresse many of those concerns. Under the CPSA, a surrogacy agreement cannot limit the right of a surrogate to make decisions safeguarding her own health or that of the fetus or embryo she is carrying. ${ }^{77}$ The agreement also cannot limit the right of the surrogate to terminate a pregnancy or reduce the number of fetuses..$^{74}$ Moreover, all parties to the surrogacy agreement have the right to terminate the agreement prior to the pregnancy without penalty.

E. CONCERNS REGARDING INFORMED CONSENT HAVE LARGELY NOT BEEN BORNE OUT AND CAN BE ADDRESSED THROUGH REGULATION

The Task Force noted concerns that surrogates who enter into surrogacy agreements may not or cannot give informed consent to an agreement that requires them to give up legal custody of a child to whom

they have given birth. According to the Task Force, a person is thought to give informed consent when a person has given consent and (i) the person possesses sufficient information to make a decision (ii) the person has the ability to understand and appreciate their decision; and (iii) the decision is voluntary and free from coercion. ${ }^{76}$ Focusing on the first two prongs of the informed consent definition the Task Force pointed out that opponents of surrogacy believe that women cannot make an informed choice to prior to a child's birth. They argue that women cannot anticipate their feelings until after the conception and birth. Those arguments were largely informed by the experience of Mary Beth Whitehead the surrogate in the Baby $M$ case, who made a very public plea to keep the child she gave birth to despite her prior agreement to relinquish custody. ${ }^{77}$

The empirical data on surrogacy arrangements, however, suggests that women are able to anticipate in advance whether or not they would be comfortable relinquishing physical and legal custody of a child they gestated. As of 2008, approximately 25,000 women in the United States had given birth through surrogacy in its contemporary form as a legal, commercial process..$^{78}$ It is estimated that over ninety-nine percent of these women willingly relinquished the child as they had agreed to do, and less than one-tenth of one percent of agreements resulted in court battles. ${ }^{79}$ In addition, empirical research suggests that the majority of surrogates have a high level of satisfaction with the process and report no psychological problems as a result of relinquishment. ${ }^{80}$ In fact, surrogate mothers in the United States have reported satisfaction and a sense of "helping" a childless individual or couple. ${ }^{81}$

The CPSA also includes mechanisms to ensure that surrogates possess sufficient information to make a decision and have the ability to understand and appreciate their decision. Anyone who becomes a surrogate must have met with doctors for a medical evaluation and receive independent legal counsel of her choosing (and also her spouse if applicable) prior to entering into any agreement. ${ }^{82}$ The CPSA also requires that a surrogate must be least 21 years old. ${ }^{83}$ This further ensures that a surrogate is capable of giving informed consent.

In sum, concerns that the New York Task Force had in 1988 are less relevant today and, to the extent they are still relevant, many of the concerns are effectively addressed by the CPSA.

\section{CHAPTER 5}

Global Surrogacy Laws

\section{SURROGACY LAWS BY COUNTRY ${ }^{84}$}

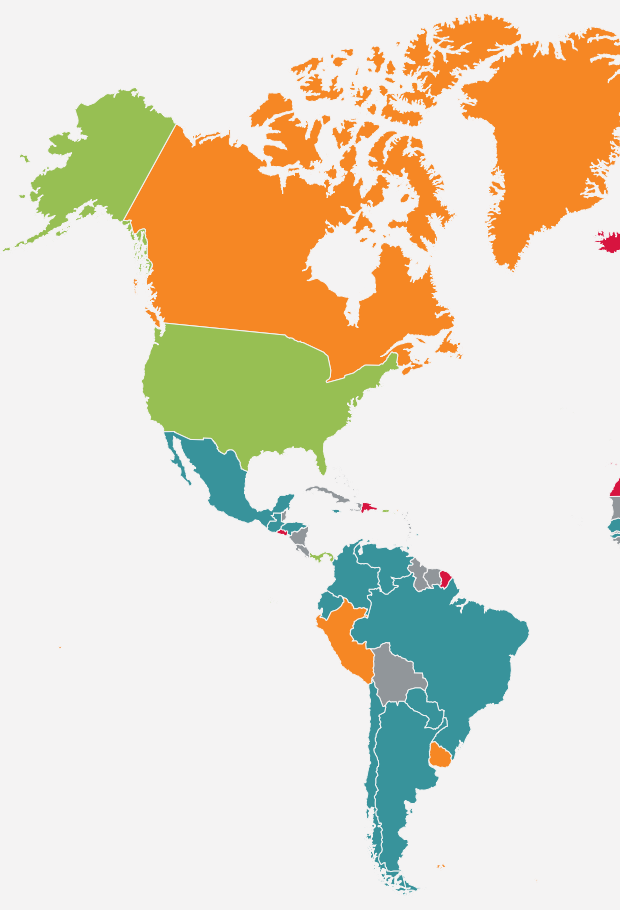

Allows compensated and

Allows uncompensated surrogacy only

Prohibits surrogacy

Has no laws governing surrogacy

Figure 3: Surrogacy Laws by Country

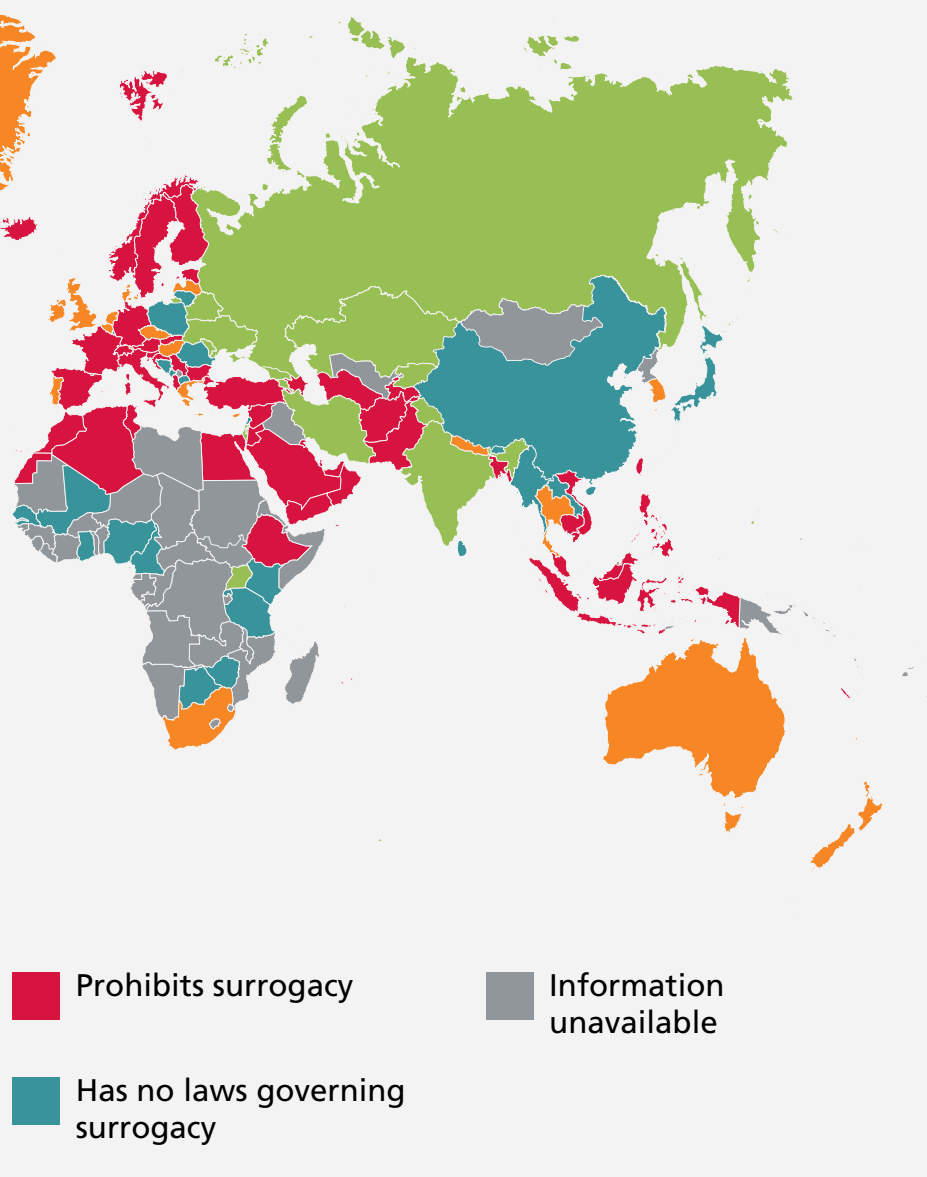




\section{TABLE 3: SURROGACY LAWS BY COUNTRY}

\begin{tabular}{|c|c|c|c|c|}
\hline $\begin{array}{l}\text { Allows } \\
\text { compensated and } \\
\text { uncompensated } \\
\text { surrogacy }\end{array}$ & $\begin{array}{l}\text { Allows } \\
\text { uncompensated } \\
\text { surrogacy only }\end{array}$ & $\begin{array}{l}\text { Has no laws } \\
\text { governing } \\
\text { surrogacy }\end{array}$ & $\begin{array}{l}\text { Information } \\
\text { unavailable }\end{array}$ & $\begin{array}{l}\text { Prohibits } \\
\text { surrogacy }\end{array}$ \\
\hline 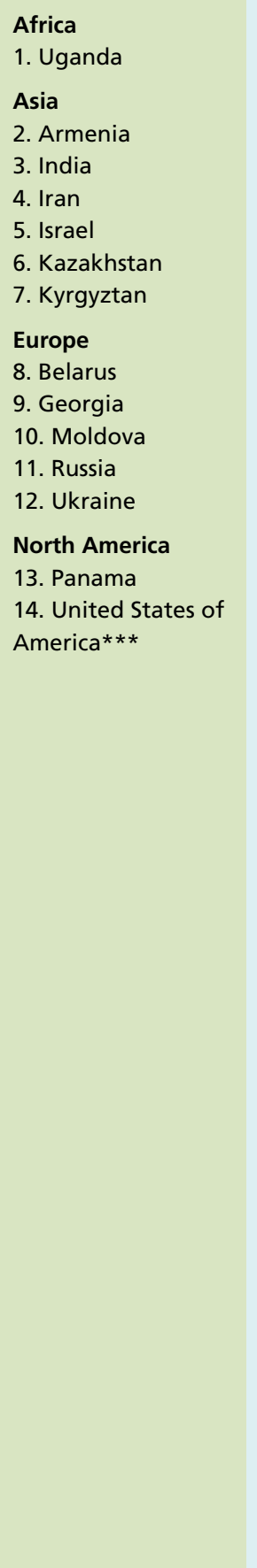 & $\begin{array}{l}\text { Africa } \\
\text { 1. South Africa } \\
\text { Asia } \\
\text { 2. Nepal } \\
\text { 3. South Korea } \\
\text { 4. Thailand } \\
\text { Oceania } \\
\text { 5. Australia**** } \\
\text { 6. New Zealand } \\
\text { Europe } \\
\text { 7. Belgium } \\
\text { 8. Cyprus } \\
\text { 9. C.ech Republic } \\
\text { 10. Denmark } \\
\text { 11. Greece } \\
\text { 12. Hungary } \\
\text { 13 Ireland } \\
\text { 14. Latvia } \\
\text { 15. Liechtenstein } \\
\text { 16. . etherlands } \\
\text { 17. Portugal } \\
\text { 18. United } \\
\text { Kingdom } \\
\text { North America } \\
\text { 19. Canada* } \\
\text { South America } \\
\text { 20. Peru } \\
\text { 21. Uruguay }\end{array}$ & $\begin{array}{l}\text { Africa } \\
\text { 1. Botswana } \\
\text { 2. Cameroon } \\
\text { 3. Ghana } \\
\text { 4. Kenya } \\
\text { 5. Mali } \\
\text { 6. Nigeria } \\
\text { 7. Rwanda } \\
\text { 8. Senegal } \\
\text { 9. Tanzania } \\
\text { 10. Zimbabwe } \\
\text { Asia } \\
\text { 11. Bhutan } \\
\text { 12. China } \\
\text { 13. Japan } \\
\text { 14. Laos } \\
\text { 15. Lebanon } \\
\text { 16. Myanmar } \\
\text { 17. Sri Lanka } \\
\text { Europe } \\
\text { 18. Bosnia \& } \\
\text { Herze-govina } \\
\text { 19. Lithuania } \\
\text { 20. Luxembourg } \\
\text { 21. Macedonia } \\
\text { 22. Monaco } \\
\text { 23. Montenegro } \\
\text { 24. Poland } \\
\text { 25. Romania } \\
\text { 26. San Marino } \\
\text { South America } \\
\text { 27. Argentina } \\
\text { 28. Brazil } \\
\text { 29. Chile } \\
\text { 30. Colombia } \\
\text { 31. Ecuador } \\
\text { 32. Paraguay } \\
\text { 33. Venezuela } \\
\text { North America } \\
\text { 34. Barbados } \\
\text { 35. Guatemala } \\
\text { 36. Honduras } \\
\text { 37. Jamaica } \\
\text { 38. Mexico** } \\
\text { 39. Trinidad and } \\
\text { Tobago }\end{array}$ & $\begin{array}{l}\text { Africa } \\
\text { 1. Benin } \\
\text { 2. Burkina Faso } \\
\text { 3. Burundi } \\
\text { 4. Cabo Verde } \\
\text { 5. Central African } \\
\text { Republic } \\
\text { 6. Chad } \\
\text { 7. Comoros } \\
\text { 8. Democratic } \\
\text { Republic of Congo } \\
\text { 9. Republic of } \\
\text { Congo } \\
\text { 10. Cote D'lvoire } \\
\text { 11. Djibouti } \\
\text { 12. Equatorial } \\
\text { Guinea } \\
\text { 13.Eritrea } \\
\text { 14.Gabon } \\
\text { 15. Gambia } \\
\text { 16. Guinea } \\
\text { 17. Guinea Bissau } \\
\text { 18. Lesotho } \\
\text { 19. Liberia } \\
\text { 20. Libya } \\
\text { 21. Madagascar } \\
\text { 22. Malawi } \\
\text { 23. Mauritania } \\
\text { 24. Morambique } \\
\text { 25. Namibia } \\
\text { 26. Niger } \\
\text { 27. Sao Tome and } \\
\text { Principe } \\
\text { 28. Seychelles } \\
\text { 29. Sierra Leone } \\
\text { 30. Somalia } \\
\text { 3. South Sudan } \\
\text { 32. Sudan } \\
\text { 33. Swaziland } \\
\text { 34. Togo } \\
\text { 35. Zambia } \\
\text { Asia } \\
\text { 36. Brunei } \\
\text { 37. riag } \\
\text { 38. Mongolia } \\
\text { 39. North Korea } \\
\text { 40. Timor Leste } \\
\text { 41. Uzbekistan }\end{array}$ & 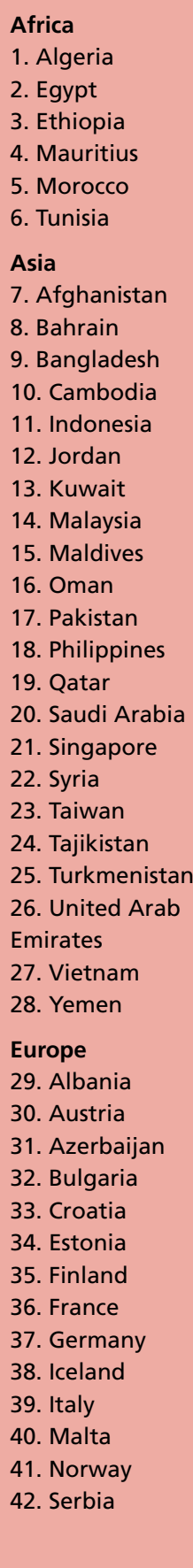 \\
\hline
\end{tabular}

\section{CONTINUED}

Information
unavailable

Prohibits
surrogacy

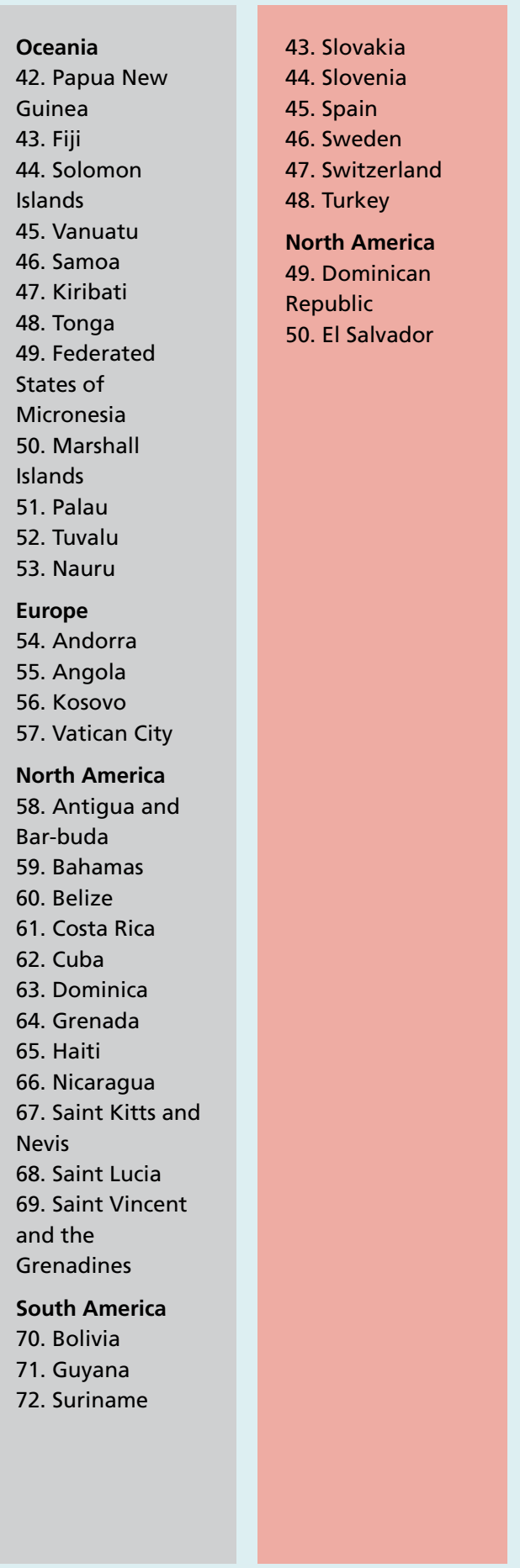

*Canada allows uncompensated surrogacy but not compensated surrogacy, with the

exception of Quebec, which bans all forms of surrogacy.

** Several states in Mexico have laws on

surrogacy either permitting or prohibiting

compensated surrogacy, but the vast majority

of states have no laws or guidelines

permitting or prohibiting surrogacy.

*** Laws in the United States vary by state,

however we have classified the country as

allowing both compensated and

uncompensated surrogacy because the

majority of states adopt a permissive

approach towards surrogacy, and all

individuals in the country can access surrogacy

by traveling to surrogacy friendly states.

$* * * *$ In the majority of Australia

uncompensated but not compensated

surrogacy is permitted, with the exception of

the Northern Territory where there is no

legislation or guidelines that directly regulate

surrogacy. 
Countries around the world have varying approaches to surrogacy. We conducted desk research to ascertain the laws of every country around the world. In many cases, we were unable to verify whether or not a country had any laws or policies relating to surrogacy and in some cases we found conflicting information about the same country. Even for countries where we found a statute, case law, or guideline in regard to surrogacy, we were sometimes unable to verify whether or not the actual practice in a country diverges from its laws. Surrogacy laws are also rapidly evolving in many countries.

Of the one hundred and ninety-six independent states in the world, fourteen countries permit both compensated and uncompensated surrogacy,

twenty-one countries permit only uncompensated surrogacy, thirty-nine countries have no regulations in regard to surrogacy, fifty countries prohibit both compensated and uncompensated surrogacy, and for seventy-two countries, we were unable to determine whether or not they had any urrogacy regulations. The map categorizes the legal regimes of countries in the world as follows: (1) countries with a statute, case law, or other guideline that explicitly permits both compensated and uncompensated surrogacy; (2) countries with a statute, case law, or other guideline that explicitly permits only uncompensated surrogacy; (3) countries where we could verify that there were no statutes, case law, or other guidelines regarding surrogacy; (4) countries for which we were unable to find any information about whether or not any statutes, case law, or other guidelines regarding surrogacy exist or where we did find information, multiple sources provided conflicting information; and (5) countries where both compensated and uncompensated surrogacy are prohibited by case law, statute, or guidelines.
Our review of global surrogacy laws gives examples of how some countries have successfully regulated surrogacy. There are three general global trends we observe in regard to surrogacy laws. First, many countries in Western Europe ban surrogacy due to religious and moral concerns. Second, several developing countries previously allowed compensated surrogacy but are now adopting a more restrictive approach, possibly because of several high-profile cases of abuse. Third, many countries have adopted a permissive but regulated approach to surrogacy.

A. MANY COUNTRIES IN WESTERN EUROPE ADOPT A RESTRICTIVE

APPROACH TO SURROGACY BASED ON RELIGIOUS AND MORAL CONCERNS.

The majority of countries in Western Europe have adopted a restrictive approach towards surrogacy agreements, prohibiting all forms of surrogacy. These countries include France ${ }^{85}$ Germany ${ }^{86}$ Italy, ${ }^{87}$ Spain, ${ }^{88}$ Austria, ${ }^{89}$ Finland, ${ }^{90}$ Iceland,,${ }^{91}$ Malta, ${ }^{92}$ Norway, ${ }^{93}$ Slovakia, ${ }^{94}$ Slovenia, ${ }^{95}$ Sweden, ${ }^{96}$ and Switzerland. ${ }^{97}$ This prohibition is often attributed to religious and moral concerns, such as concerns that surrogacy commodifies women and children and that surrogacy violates the surrogate mother's and the child's human dignity. For example, the driving force behind Italy's ban on surrogacy is the Catholic Church, and Catholic bishops supporting the ban are said to have discouraged Italians from voting to change the law in $2005 . .^{98}$ In the case of France, legislators feel that surrogacy conflicts with its laws protecting human dignity ${ }^{99}$ Many of these countries adopt a relatively restrictive approach to biomedicine more generally, based on concerns about human dignity. For example, France, Spain, Iceland, Slovakia, and Slovenia have all ratified the Ovideo Convention, a convention adopting a restrictive approach to biomedicine. ${ }^{100}$ Notably, the United Kingdom did not ratify this treaty on the basis that it was too restrictive, while Germany did not ratify the treaty on the basis that it was too permissive ${ }^{101}$

\section{CASE STUDY - FRANCE}

France is a primarily Catholic country located in Western Europe, and completely prohibits surrogacy. In France, engaging in surrogacy is punishable with significant fines and imprisonment.

France initially did not recognize the parent-child relationship established by pare couples who proceded with surrogacy abroad, but the European Court of Human Rights ruled that this violated the child's right to respect for private and family life.

The number of parents who have tried to circumvent the prohibition has given rise to significant debates and proposed reforms.

According to a blog post by Claire Legras, a member of the French National Committee on Bioethics, the French ban is driven by concerns that surrogacy is inherently exploitative because of the typical difference in bargaining power between parties to surrogacy arrangements, concerns that children born to surrogates may suffer psychological damage, and concerns that surrogacy commodifies children.

Sources: Civil Code arts. 16-17; arts. 227-12, 227-13, 11-24 Penal Code, Laborie v. France, no. 44024/13 ECHR 2017; Louis Perreua-Saussine \& Nichola

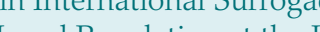
Level 119, 127-130 (Katriona Trimminos \& Paul Beaumont eds., 2013).

To avoid restrictive laws in their own countries, some people living in those countries have made surrogacy arrangements abroad, and some prohibitionist countries then refused to recognize the parental rights of intended parents. However, the European Court of Human Rights ruled that France's refusal to recognize the parent-child relationship between a couple and two children born to a surrogate in California violated the surrogate children's right to respect for their private life under Article 8 of the European Convention on Human Rights. ${ }^{102}$ On the other hand, the European Court of Human Rights subsequently held that there was no violation of Article 8 when a child, who was born to a surrogate in a foreign country, was removed from parents in Italy because the Italian couple were not biologically related to the child and had not spent a significant amount of time with the child. ${ }^{103}$

B. LACK OF REGULATION AND TRANSNATIONAL DEMAND LEAD TO ABUSES IN SEVERAL LESS DEVELOPED COUNTRIES

Several countries with previously thriving surrogacy markets have recently adopted a more restrictive approach to surrogacy. This has happened, at least in part, due to problems arising from a huge proliferation in surrogacy over a short period of time combined with a lack of legal regulation of the industry, leading to several highprofile cases of abusive practices. These countries include Nepal, ${ }^{104}$ Thailand, ${ }^{105}$ India, ${ }^{106}$ and parts of Mexico. ${ }^{107}$ Each of these countries or regions

within these countries have banned surrogacy for foreign couples amid concerns over exploitation of surrogates, and oversight and safety of the surrogacy industry. ${ }^{108}$ For example, Thailand banned compensated surrogacy after two high profile cases-one in which Australian intended parents abandoned a child with Down syndrome, and another where a Japanese man was found to have fathered more than a dozen babies by different Thai surrogates. ${ }^{109} \mathrm{Nepal}$ also banned commercial surrogacy through a decision of the Supreme Court of Nepal in 2016. ${ }^{110}$ This was partly in response to media coverage of the evacuation of surrogate babies but not surrogate mothers after a major earthquake in $2015 .{ }^{111}$ Similarly, India has adopted an increasingly restrictive approach to surrogacy following high transnational demand and concerns about exploitation, resulting in the Indian government banning foreigners from entering into surrogacy arrangements in India. ${ }^{112}$ In 2016, the Indian Parliament proposed the 2016 Surrogacy (Regulation) Bill (the 2016 Bill) that 
would ban compensated surrogacy entirely while allowing uncompensated surrogacy. The principle reason articulated by the government for the ban is to protect Indian women who act as surrogates from being exploited. ${ }^{113}$ External Affairs minister and Bharatiya Janata Party leader Sushma Swaraj has been a vocal proponent of the 2016 Bill. She has spoken out against Bollywood celebrities using compensated surrogacy to avoid the impacts of pregnancy on their bodies. In addition, she has suggested that it is appropriate to prohibit samesex couples from surrogacy because allowing it, "doesn't go with our ethos.". ${ }^{114}$ Swaraj and the government have taken the stance that prohibiting compensated surrogacy is necessary to protect women from exploitation. Instead of compensated surrogacy, Swaraj and the government propose that" [c] hildless couples, who are medically unfit to have children, can take help from a close relative, which is called altruistic surrogacy." ${ }^{115}$

\section{MANY COUNTRIES PERMIT AND} REGULATE SURROGACY

Countries that allow compensated and uncompensated surrogacy include Georgia, ${ }^{116}$ Russia, ${ }^{117}$ Ukraine, ${ }^{118}$ and Israel. ${ }^{119}$ These countries have legal frameworks that regulate surrogacy practice. For example, in Israel, a ban on surrogacy was lifted and regulation was introduced in 1996. ${ }^{120}$ Surrogacy is now allowed but is heavily regulated. Israel's surrogacy law aims to prevent the exploitation of women and requires an approving committee to ensure the surrogate's informed consent and well-being. ${ }^{121}$ This committee also supervises compensation including recommending monthly payments to the surrogate to cover medical expenses, insurance, legal consultation, loss of time and income, suffering, and other reasonable compensation and ensuring there is no"illegal commercialization" of the surrogacy procedure. ${ }^{122}$

\section{CASE STUDY - INDIA}

India is a majority Hindu country in South Asia with a significant Muslim population. Compensated surrogacy in India began with the commissioning of India's first surrogate in 1997. India developed into a global hub for surrogacy, but the government initially did very little to establish a regulatory framework to govern the industry.

In 2015, the Indian government banned foreigners from engaging in surrogacy in India.

In the same year, Jayashree Wad, an advocate on record in the Indian Suprem Court filed a Public Interest Litigation challenging compensated surrogacy in India. Her primary contentions were that surrogacy agreements commercialized surrogacy agreements commercialized
women's wombs, led to adverse health women's wombs, led to adverse heath
consequences, and that surrogacy agreements lacked informed consent and were generally exploitative.

The Indian Parliament is considering the Surrogacy (Regulation) Bill of 2016, which would ban compensated surrogacy entirely while still allowing uncompensated surrogacy.

Sources: Normann Wizleb \& Anurag Chawla, Demand, Weak Laws, in Surrogacy, Law, and Human Rights 167, 176-178 (Paula Gerber \& Katie O'Byrne eds. 2015); Bin Shajan Perappadan, A setback for surrogacy
India? The Hindu (Nov. 29, 3.04AM), India? The Hindu (Nov. 29, 3.04AM) http://www.thehindu.com/opinion/op-ed/a setback-for-surrogacy-in-india/article7927
Sonali Kusum, Public interest litiagation PI surrogacy in India 2 Legal Judicial thesthrusurrogacy.co m/wp-content/uploads/2016/05/Indian-SurrogacyBill-Background-latest-developments.pdf.

\section{CASE STUDY - ISRAEL}

Israel is a country in the Middle East that has adopted a permissive approach to surrogacy. Israel allows both compensated and uncompensated surrogacy under legislation adopted in 1996.

Israel banned surrogacy in the aftermath of the Baby $M$ case in the United States, but many scholars were of the view that this violated constitutional rights in Israel. this violated constitutional rights in Is operated against human freedom, dignity, and privacy, which include the right to assisted reproductive technology as well as the right of every person to become a parent. This argument led to the legalization of surrogacy in 1996.

Israeli surrogacy contracts must be in writing, and every surrogacy contract must be approved directly by a state-appointed committee.

The state-appointed committee ensures the consent and well being of the surrogate and supervises compensation. Compensation typically includes medical expenses, insurance, legal consultation, loss of time and income, suffering, and other reasonable compensation. The committee ensures that there is no "illegal commercialization" of the procedure.

The surrogate cannot be forced to regulate her lifestyle by the intended parents and the intended parents cannot force the surrogate to undergo any invasive medical procedure, including an abortion.

The surrogate must be an unmarried woman, anonymous, and not a relative of the couple. The surrogate must be of the same religion as the intended parents (because under Jewish law, the child acquires the religion of the birth mother).
The parties must be Israeli residents and above the age of eighteen. The intended mother must be unable to bear a child, the intended parents must be a heterosexual married couple, and the gametes must be provided by the intended parents.

A medical and psychological examination of all the parties is conducted.

The intended parents must adopt the child that is born through surrogacy, with a social worker acting as the guardian of the child until the formal adoption process is completed with the approval of the court. The intended parents must issue a request for adoption within seven days of the birth of the child, which is typically approved by the couts, which makes its decision based the court, which makes its decision
on the best interests of the child.

Sources: Embryo Carrying Agreements (Approval of the Agreement and the Status of the Child) Law, SH Contested surrogacy and the gender order: An Israel case study, $3 \mathrm{~J}$. of Middle East Women's Studies 21, International Surrogacy Arrangements: Legal Regulation at the International Level 231, 231-2 (Katarina Trimmings \& Paul Beaumont eds., 2013); Joseph G. Schenker, Legal Aspects of ART Practice in Israel, Journal of Assisted Reproduction and

Other countries (such as most of Canada, ${ }^{123}$ most of Australia, ${ }^{124}$ and South Africa ${ }^{125}$ ) prohibit compensated surrogacy (including payments for loss of time and income) but regulate uncompensated surrogacy. For example, South African law makes uncompensated surrogacy agreements legally enforceable and regulates the practice by requiring that a surrogate mother be a suitable person with an understanding of the legal consequences and obligations involved in a surrogacy agreement. ${ }^{126}$ Surrogacy agreements are required to be in writing and confirmed by an appropriate High Court. ${ }^{127}$ 


\section{CASE STUDY - SOUTH AFRICA}

South Africa, the southernmost country in Africa, allows and regulates

uncompensated surrogacy but not

compensated surrogacy.

The surrogacy agreement must be signed

by all parties and must be entered into in South Africa. One of the intended parents must be domiciled in South Africa when entering the agreement and the surrogate mother and her partner (if any) must be domiciled in South Africa.

The surrogacy agreement has to be confirmed by the High Court in the jurisdiction the intended parent(s) are domiciled. No surrogacy can take place without the court confirming the agreement or after the lapse of 18 months since confirmation.

The court may not confirm a surrogacy agreement unless it is satisfied, taking int account the personal circumstances and family situations of all parties, but above all the interests of the child that is to be born, that the agreement should be confirmed.

Surrogacy agreements are legally enforceable.

The intended parent(s) entering the agreement must not be able to give birth to a child due to a condition that is permanent and irreversible. They must also be suitable persons to accept the parenthood of the child conceived and must realize the legal consequences and obligations arising from the surrogacy agreement.

Intended parent(s) can be single or a couple. If the intended parents are a couple, the court may not confirm the agreement unless both partners consent to the agreement.
The surrogacy agreement is not valid unless the conception of the child contemplated in the agreement is to be effected by the use of the gametes of both intended parents or, if that is not possible due to biological, medical, or other valid reasons, the gamete of at least one of the intended parents.

The surrogate must be competent to enter into the contract, and must be a suitable person to act as a surrogate

understanding the legal consequences and obligations arising from the surrogacy contract). The surrogate must have a documented history of at least one pregnancy and a living child of her own. She must not be using this as a source of income and must be entering into the agreement for altruistic purposes.

The decision to terminate the pregnancy lies with the surrogate, but she must inform with and consult with the intended parents prior to her decision.

Any child born of a surrogate in

accordance with a surrogacy agreement is, for all intents and purposes, the child of the intended parents from birth.

The surrogate can claim expenses relating to the pregnancy, the birth of the child, confirmation of the surrogacy agreement loss of earnings, and related health insurance. Compensated surrogacy is prohibited.

2005 Act No 38 of 2005: Ex parte WH 2011 6 SA 514 (GNP).
D. COMPARING THE CPSA TO GLOBAL

\section{SURROGACY LAWS}

Current New York law is similar to restrictive laws prohibiting surrogacy in Western European countries such as France, Germany, and Italy. However, this restrictive approach is at odds with the more permissive approach to other biomedical procedures generally adopted in New York (such as allowing sex selection as part of IVF procedures).

Moreover, the European approach is largely

influenced by religious and moral concerns. While these concerns are relevant, they should not be the only guiding force in legislative decision-making in New York.

The CPSA would bring New York in line with many other states and many countries globally by permitting but regulating surrogacy. The CPSA contains many provisions similar to those in regulated systems globally_including protecting the rights of surrogates by allowing the surrogate to make decisions relating to medical procedures and recognizing the intended parents as the parents from birth (as in South Africa). However the CPSA does not go as far as some regulatory systems, such as South Africa

and Israel, as it does not require approval of surrogacy contracts by a state body. In fact, no American state has such a requirement.

Ultimately, countries that adopt a restrictive approach to surrogacy appear to do so either based on religious and moral concerns, or based on the proliferation of surrogacy contracts accompanied by a lack of regulation, leading to exploitative situations and negative perceptions of surrogacy. Other countries with permissive approaches to surrogacy provide useful examples of how nations regulate surrogacy. 


\section{CHAPTER 6}

\section{International Human}

Rights Treaties Support Legalization of Surrogacy

International human rights treaties and norms create important standards for New York to consider in regulating surrogacy. Those treaties address the rights of children, rights of surrogates, and rights of intended parents. The United States has signed and ratified a number of international human rights treaties. State governments are bound by international treaties that the United States has ratified..$^{128}$ In respect of treaties that the United States has only signed but not ratified, states should refrain from defeating the object and purpose of the treaty. Below we describe the relevant provisions of each treaty from the perspective of the relevant actors and point out that the treaties do not require that surrogacy be prohibited, but rather, generally support its legalization.

\section{A. SURROGACY DOES NOT} CONTRAVENE THE RIGHTS OF CHILDREN

The United States has signed and ratified the Optional Protocol to the United Nations Convention on the Rights of the Child, on Sale of Children, Child Prostitution, and Child Pornography. ${ }^{129}$ Article 1 of that Optional Protocol obligates governments to criminalize, amongst other things, the sale of children, ${ }^{130}$ which is defined as"any act or transaction whereby a child is transferred by any person or group of persons to another for remuneration or any other consideration." ${ }^{131}$ The United States has signed but not ratified the United Nations Convention on the Rights of the Child (the CRC), ${ }^{132}$ Article 2 of which also prohibits the sale of children. ${ }^{133}$
The CRC and Optional Protocol are intended to prevent children from being sold into abusive and exploitative situations and to prevent parents who might otherwise sell their children due to their poverty. The surrogacy arrangement as contemplated by the CPSA would involve compensation for the gestational care provided by the surrogate and not compensation for the purchase of a child or for the transfer of that child (who is always the legal and often the genetic child of the intended parent(s)). In addition, the person or people who engage a gestational carrier to carry a child are the ones that are considered the legal parents under the CPSA immediately upon birth of the child. ${ }^{134}$ Thus, the intended parents would be taking custody of their own child after he or she is born and not purchasing him or her.

\section{B. PERMITTING SURROGACY PROMOTES} WOMEN'S REPRODUCTIVE AUTONOMY

The United States has signed and ratified the International Covenant on Civil and Political Rights (ICCPR). ${ }^{135}$ Article 17 of the ICCPR provides for the right to privacy, which has been interpreted to include aspects of reproductive autonomy. For example, in Karen Noelia Llantoy Huamán v. Peru the Human Rights Committee recognized the right to have an abortion as part of the right to privacy. ${ }^{136}$ The United States has signed (but not ratified) another relevant treaty - the International Covenant on Economic, Social, and Cultural Rights (ICESCR). ${ }^{137}$ Article 12 of the ICESCR states that signatories must provide the right to health, which includes the right to sexual and reproductive freedom as well as the freedom to decide the medical treatment administered to oneself. ${ }^{138}$ The ICESCR also includes the right to work in Articles 6 and 7. This encompasses the right to freely decide to accept or choose to work. ${ }^{139}$ Another relevant treaty is the Convention on the Elimination of all Forms of Discrimination Against Women (CEDAW), which the United States has signed but not ratified. ${ }^{140}$ Article 16 of CEDAW states that women have the right to decide freely the number and temporal spacing of their children. ${ }^{141}$
Permitting a woman to choose to provide gestational care is consistent with her right to reproductive autonomy enshrined in the ICCPR. The ICESCR further notes that a woman has the right to make her own reproductive decisions and also has the right to work. CEDAW also suggests that women should have the right to decide whether and when to have children. Taken together, these treaties suggest that women should have control over their reproductive capacities, including the ability to decide whether to be a surrogate. On the other hand, restricting a woman's right to choose may contravene some of these treaties. Accordingly, the CPSA specifically provides that any contract provision that restricts a surrogate's right to terminate her pregnancy is not enforceable. ${ }^{142}$

\section{SURROGACY ALLOWS PEOPLE TO} FOUND A FAMILY

Article 23(2) of the ICCPR states all people have the right to "found a family." ${ }^{\prime 143}$ The Human Rights Committee further elaborated that this right to found a family includes the right to procreate. ${ }^{144}$ While this provision does not mandate legalization of surrogacy, it certainly weighs in its favor. This is particularly true with the recognition that samesex couples have a right to marry. ${ }^{145}$ For male same-sex couples, surrogacy may be the only option for them to have children that are genetically related to at least one of them.

The CPSA would repeal prohibitions on a woman's ability to receive compensation for providing gestational care and would allow intended parents who could not otherwise have children to found a family. In addition, as structured in the CPSA, the surrogacy arrangement would not constitute selling children. 


\section{CHAPTER 7}

\section{Conclusion and Recommendation}

We recommend that New York adopt the CPSA.

New York is one of two states in the United States that criminalizes compensated surrogacy and refuses to enforce even uncompensated surrogacy contracts. This does not prevent New Yorkers from obtaining gestational care. Instead, they contract with surrogates from other states but this can lead to uncertainty over parentage, and legal, financial, and practical challenges.

The concerns that led New York to prohibit surrogacy a quarter of a century ago are less relevant today. The Task Force on Life and the Law recommended banning surrogacy because the echnology was still new and its societal implications unclear. Empirical data from states across the U.S. where surrogacy is legal along with changing societal norms suggest that many of the Task Force's concerns should no longer inform the surrogacy debate today.

Countries around the world take differing approaches to surrogacy and many provide examples of strong regulatory models. When practiced appropriately and as set forth in the CPSA, surrogacy would not violate international human rights treaties. In fact, legalizing surrogacy would be consistent with the treaties' stated goal by protecting intended parents' right to found a family and a woman's right to reproductive autonomy.
Based on a review of surrogacy regulations in other U.S. states and other countries, the New York legislature could consider including additional provisions in the CPSA. First, require surrogates to undergo a psychological screening prior to entering into a surrogacy agreement. Second, require surrogates to have given birth to at least one child previously. Third, require that surrogacy contracts cannot include provisions regulating a surrogate's lifestyle. Even if these provisions were not include in the CPSA, we still recommend that New York should enact the CPSA or some version of it that legalizes surrogacy in New York.

\section{Acknowledgments}

PRINCIPAL AUTHORS

Sital Kalantry, Clinical Professor of Law and Directo International Human Rights: Policy Advocacy Clinic Cornell University Law School

Rebecca K. Helm, Lecturer in Law at the University of Exeter and former Clinic Teaching Fellow, International Human Rights: Policy Advocacy Clinic, Cornell University Law School.

Aparna Chandra, Assistant Professor of Law and Research Director, Center for Constitutional Law, Policy and Governance, National Law University, Delhi.

Mrinal Satish, Associate Professor of Law an Executive Director, Center for Constitutional Law, Policy and Governance, National Law University, Delhi.

\section{PROJECT CONSULTANT}

Bradley Wendel, Professor of Law, Cornel University Law School.

PRINCIPAL RESEARCHERS AND CONTRIBUTING AUTHORS FROM CORNELL INTERNATIONAL HUMAN RIGHTS: POLICY ADVOCACY CLINIC

Samantha Elliott*

Stefan Golubovi

ames Kruger

Alle

Shannon Nakamoto

Kimberly Petrick

Raaga Sanjeev

Jaeeun Shin

Ayusmita Sinha

Aashim Usgaonka

ulian Veintimilla

*Teaching Assistant
PRINCIPAL RESEARCHERS AND CONTRIBUTING AUTHORS FROM NATIONAL LAW UNIVERSITY DELHI

Shrutanjay Bhardwaj

Aradhana CV

Shweta Kabra

Jagata Krishnaswaminathan

Aarushi Mahajan

Keerthana Medarametla**

Mona Nooreyezdan

Malavika Parthasarathy

Sonal Sarda

** Teaching Fellow

We are grateful to organizations and individuals who helped us in the United States and in India, includin Akanksha Hospital and Dr. Nayana Patel, Fertility Donor Solutions Assisted Reproductive Technology Bank, the Embassy of the United States in Delhi, the Indian Council of Medical Research, the National Commission for Women in India, SAMA the Gupta Clinic, Women's Bar Association of the State of New York, International Women's Rights Committee, Health Law \& Reproductive Rights Committee, Finger Lakes Women's Bar Association Surabhi Sherm, Mary John

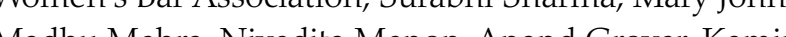
Madhu Mer As, Nocing Jaiswal, Dr. Ashok Gupta, Radhika Thapar Bahl, Cynth Frucht Swain, Karen Smith Rotabi, Kathleen McRoberts, Manasi Mishra Trupti Rajendra Raiput, Dr Ragin Manasi Mishra, Trupti Rajendra Rajput, Dr. Ragini Aggarwal, Dr. Manju Dagar, Dr. Mohan Rao, Dr. Romila Dr. Rama, Hema Sahu, Sushmita Dev, Gita

Aravamudan, Honorable Kalikesh Narayan Singh Deo, Dr. Surabhi Gupta, Nidhi Kataria, Neha Tiwari, Bulbul Dhar, Ishani K. Dutta, Sahaj, Sarita, Suzanne I. Seubert, Bruce Hale, Dr. Joel Batzofin, Professor Kalindi Vora, an to every other organization and individual who we consulted with. We are indebted to Aanchal Kapur and the Kriti Team for their support and coordination of many important interviews and meetings for our team. Finally, thank you to Doug Wagner and Brad Lenox for their assistance in preparing the report. We would like to recognize and thank the surrogates who gave their time to speak to

The views in this report do not necessarily represent the views of the individuats and organizations we met wh. 
${ }^{3}$ David Beresford, Test tube mother has girl, GUARDIAN, July 26, 1978, available at https://www.theguardian.com/ theguardian/from-the-archive-blog/2011/jun/02/ guardian190-test-tube-baby-1978.

${ }^{4}$ Mayo Clinic Staff, In vitro fertilization (IVF), MAYO CLINIC, http://www.mayoclinic.org/tests-procedures/invitro-fertilization/home/ovc-20206838 (last visited July 8, 2017).

${ }^{5}$ Diane S. Hinson \& Maureen McBrien, Surrogacy Across America, FAMILY ADVOCATE 32, 33 (2011). ${ }^{6}$ In re Baby M, 537 A.2d 1227 (N.J. 1988). 7 Carla Spivack, The Law of Surrogate Motherhood in the United States, 58 AM. J. COMP. L. 97, 101 (2010). ${ }^{8} \mathrm{NEW}$ YORK STATE TASK FORCE ON LIFE AND HEALTH, Surrogate Parenting: Analysis and Recommendations for Public Policy (1998), https://www.health.ny.gov/ regulations/task_force/reports_publications/docs/ surrogate_parenting.pdf [hereinafter N.Y. TASK FORCE, Surrogate Parenting].

${ }^{9} / d$.

${ }^{10} / \mathrm{d}$

${ }^{11}$ N.Y. DOM. REL. LAW $\S 122$ (McKinney 2010).

${ }^{12} / d . \S 123$

${ }^{13} / d$. $\$ 123(2)(a)$

${ }^{14} / d$. $\S 123(2)(b)$

${ }^{15} / d . \S 124(1)$.

${ }^{16}$ See Itskov v. N.Y. Fertility Inst., 813 N.Y.S.2d 844 (N.Y. App. Term 2006)

${ }^{17} \mathrm{ld}$. at 844-46.

${ }^{18}$ Interview by Cornell International Human Rights Clinic with New York surrogacy attorney (Mar. 21, 2017) [hereinafter Interview with New York attorney].

${ }^{19}$ Child-Parent Security Act, Assemb.B. A-6959A, Reg. Sess. 2017-18 \& 581-401 (N.Y. 2017), available at http:// legislation.nysenate.gov/pdf/bills/2017/A6959A [hereinafter CPSA].

${ }^{20} / d$. $\S 581-502(B)$.

${ }^{21} / d$. $\$ 581-405(\mathrm{~A})(6)$.

${ }^{22} l d . \S 581-502(\mathrm{~A})$.

${ }^{23} / d . \$ 581-502(\mathrm{D})$

${ }^{24} / d$. § 581-405(A)(7).
${ }^{26} / d . \S \S 581-102,581-103$.

${ }^{27} / d$. $\S 581-303$.

${ }^{28} / d$.

${ }^{29} / d . \S 581-102(\mathrm{~B})$

${ }^{30} / d$. $\$ 581-401(\mathrm{D})$

Id. § 581-405(A)(7)(I)(C)

${ }^{33} / d$. $\S 581-406$.

${ }^{34} / d$. $\$ 581-404$.

${ }^{35} / d$. $\S 581-404(\mathrm{~A})(4)$

${ }^{36}$ See Joan Cary, Surrogate Births Growing in Popularity, CHIC. TRIB. (Oct. 9, 2013), http://www.chicagotribune. com/lifestyles/health/ct-x-1009-surrogate-20131009story.html; Jennifer Paris, Surrogacy Becomes a Viable Option, CTPOST (Mar. 26, 2012), http://www.ctpost.com/ home/article/Surrogacy-Becomes-a-Viable-

Option-3377488.php; Michael Ollove, Some States Create Welcoming Environment for Surrogacy, PEW CHARITABLE TR. (Nov. 6, 2015), http://www.pewtrusts. org/en/research-and-analysis/blogs/stateline/2015/11/06/ some-states-create-welcoming-environment-forsurrogacy.

${ }^{37}$ Seema Mohapatra, States of Confusion: Regulation of Surrogacy in the United States, in NEW CANNIBAL MARKETS: GLOBALIZATION AND COMMODIFICATION OF THE HUMAN BODY (J.D. Rainhorn \& S. EI

Boudamoussi eds., 2015).

${ }^{38}$ NEB. REV. STAT. $25-21$ (2007).

${ }^{39}$ Gestational Surrogacy in Nebraska, CREATIVE FAMILY CONNECTIONS, http://www.creativefamilyconnections. com/us-surrogacy-law-map/nebraska (last visited Apr. 27, 2017)

${ }^{40}$ ARIZ. REV. STAT. § 25-218 (2011).

${ }^{41}$ Telephone Interview by Cornell Law School Human Rights Clinic with Arizona attorney (Mar. 28, 2017) [hereinafter Interview with Arizona attorney].

${ }^{42}$ Soos v. Super. Ct. Cty. of Maricopa, 897 P.2d 1356 (Ariz. Ct. App. 1994)

${ }^{43}$ Interview with Arizona attorney, supra note 42. ${ }^{44}$ Richard F. Storrow, Surrogacy American Style, in SURROGACY, LAW, AND HUMAN RIGHTS 191, 198 (Paula Gerber \& Katie O'Byrne, eds., 2015).

${ }^{45}$ D.C. CODE ANN. § 16-404 (2017).

${ }^{46}$ See MICH. COMP. LAWS ANN. 722.851 et seq.

${ }^{47}$ Alabama, compensated surrogacy is permitted since no statute or published case law prohibits it. Gestational Surrogacy in Alabama, CREATIVE FAMILY CONNECTIONS, http://www.creativefamilyconnections.com/us-surrogacylaw-map/alabama (last visited Apr. 27, 2017); Alaska, compensated surrogacy is permitted since no statute or published case law prohibits it. Gestational Surrogacy in Alaska, CREATIVE FAMILY CONNECTIONS, http://www. creativefamilyconnections.com/us-surrogacy-law-map/ alaska (last visited Apr. 27, 2017); Arizona, ARIZ. REV. STAT. § 25-218 (2011) (stating that no person may enter into or assist in creating a surrogacy contract); Arkansas, ARK. CODE ANN. § 9-10-201 (2010); California, CAL. FAM. CODE §§ 7960-7962 (2013); Colorado,

compensated surrogacy is permitted since no statute or published case law prohibits it. Gestational Surrogacy in Colorado, CREATIVE FAMILY CONNECTIONS, http://www. creativefamilyconnections.com/us-surrogacy-law-map/ colorado (last visited Apr. 27, 2017); Connecticut, CONN. GEN. STAT. § 7-48a (2012); Delaware, DEL. CODE ANN. tit. 13, §§ 8-801 to 8-813 (2013); District of Columbia, D.C. CODE ANN. § 16-404 (2017); Florida, FLA. STAT. ANN. § 742.13-742.16 (2016); Georgia, compensated surrogacy is permitted since no statute or published case law prohibits it. Gestational Surrogacy in Georgia, CREATIVE FAMILY CONNECTIONS, http://Www. creativefamilyconnections.com/us-surrogacy-law-map/ georgia (last visited Apr. 27, 2017); Hawaii, compensated surrogacy is permitted since no statute or published case law prohibits it. Gestational Surrogacy in Hawaii, CREATIVE FAMILY CONNECTIONS, http://www. creativefamilyconnections.com/us-surrogacy-law-map/ hawaii (last visited Apr. 27, 2017); Idaho, compensated surrogacy is permitted since no statute or published case law prohibits it. Gestational Surrogacy in Idaho, CREATIVE FAMILY CONNECTIONS, http://www. creativefamilyconnections.com/us-surrogacy-law-map/ idaho (last visited Apr. 27, 2017); Illinois, 750 ILL. COMP. STAT. §§ 47/1-75 (2005); Indiana, IND. CODE § 31-20-1-1 (2006); lowa, IOWA CODE $\$ 710.11$ (2016) (prevents surrogacy agreements from being categorized as the sale of children); Kansas, compensated surrogacy is permitted since no statute or published case law prohibits it. Gestational Surrogacy in Kansas, CREATIVE FAMILY CONNECTIONS, http://www.

creativefamilyconnections.com/us-surrogacy-law-map/ kansas (last visited Apr. 27, 2017); Kentucky, compensated surrogacy is permitted since no statute or published case law prohibits it. Gestational Surrogacy in Kentucky, CREATIVE FAMILY CONNECTIONS, http://www. creativefamilyconnections.com/us-surrogacy-law-map/ Kentucky (last visited Apr. 27, 2017) (Kentucky does prohibit traditional surrogacy, see KY. REV. STAT. ANN. § 199.590 (West 2005)); Louisiana, LA. STAT. ANN. 9:2719 (2016) (explicitly prohibiting traditional surrogacy); LA. STAT. ANN. 9:2720(c) (2016) (explicitly prohibiting compensated surrogacy); Maine, ME. STAT. tit. 19-A, § 1931 (2015); Maryland, Gestational Surrogacy in Maryland, CREATIVE FAMILY CONNECTIONS, http:// www.creativefamilyconnections.com/us-surrogacy-lawmap/maryland (last visited Apr. 27, 2017); Massachusetts, see R.R. v. M.H., 689 N.E.2d 790 (Mass. 1998); Hodas v. Morin, 814 N.E.2d 320 (Mass. 2004) (enforcing a surrogacy contract by applying Massachusetts law); Michigan, MICH. COMP. LAWS $\$$ 722.855-859 (1988) (making surrogacy contracts void and unenforceable and criminalizes surrogacy for compensation); Minnesota, P.G.M. v. J.M.A. (In re Baby Boy A.), 2007 Minn. App. Unpub. LEXIS 1189, *1 (Minn. Ct. App. Dec. 11, 2007) (noting that, while Minnesota has no laws sanctioning such agreements, it also lacks laws against them, and has other laws protecting the rights of those who used assisted reproduction technologies); Mississippi, compensated surrogacy is permitted since no statute or published case law prohibits it. Gestational Surrogacy in Mississippi, CREATIVE FAMILY CONNECTIONS, http://www. creativefamilyconnections.com/us-surrogacy-law-map/ mississippi (last visited Apr. 27, 2017); Missouri,

compensated surrogacy is permitted since no statute or published case law prohibits it. Gestational Surrogacy in Missouri, CREATIVE FAMILY CONNECTIONS, http://www. creativefamilyconnections.com/us-surrogacy-law-map/ missouri (last visited Apr. 27, 2017): Montana,

compensated surrogacy is permitted since no statute or published case law prohibits it. Gestational Surrogacy in Montana, CREATIVE FAMILY CONNECTIONS, http://www. creativefamilyconnections.com/us-surrogacy-law-map/ montana (last visited Apr. 27, 2017); Nebraska, NEB. REV. STAT. 25-21, 200 (2007) (making compensated surrogacy contracts unenforceable, although note that law also makes biological father of children born from surrogacy sole legal parent of resulting child): Nevada NEV REV. 
STAT. §§ 126.500-126.810 (2013) (legalizing gestational surrogacy, but not traditional surrogacy); New Hampshire, N.H. REV. STAT. ANN. 168-B (2014); New Jersey, A.H.W. v. G.H.B., 772 A.2d 948 (N.J. Super. Ct. Ch. Div. Fam. Part 2000); In re T.J.S., 54 A.3d 263 (N.J. 2012), note that compensated surrogacy is prohibited but uncompensated surrogacy is permitted; New Mexico, N.M. STAT. ANN. § 40-11A801 (2011); New York, N.Y. DOM. REL. LAW § 122 (McKinney 2010); North Carolina, compensated surrogacy is permitted since no statute or published case law prohibits it. Gestational Surrogacy in Nort Carolina, CREATIVE FAMILY CONNECTIONS, http www.creativefamilyconnections.com/us-surrogacylaw-map/north-carolina (last visited Apr. 27, 2017); North Dakota, N.D. CENT. CODE §§ 14-18-08 (legalizing gestational surrogacy); but see N.D. CENT. CODE §§ 14-18-05 (prohibiting traditional surrogacy); Ohio, J.F. v. D.B., 879 N.E.2d 740 (Ohio 2007) (holding that surrogacy contracts are enforceable in Ohio and not against public policy); Oklahoma, compensated surrogacy is permitted since no statute or published case law prohibits it. Gestational Surrogacy in

Oklahoma, CREATIVE FAMILY CONNECTIONS, http:/ www.creativefamilyconnections.com/us-surrogacylaw-map/oklahoma (last visited Apr. 27, 2017)

Oregon, compensated surrogacy is permitted since no statute or published case law prohibits it. Gestational Surrogacy in Oregon, CREATIVE FAMILY CONNECTIONS, http://www.

creativefamilyconnections.com/us-surrogacy-law-map/ oregon (last visited Apr. 27, 2017); Pennsylvania, J.F. v. B.D., 897 A.2d 1261 (Pa. 2006) (granting custody to biological father, rather than surrogate, but refusing to definitively hold whether surrogacy contracts are enforceable); Rhode Island, compensated surrogacy is permitted since no statute or published case law prohibits it. Gestational Surrogacy in Rhode Island, CREATIVE FAMILY CONNECTIONS, http://www. creativefamilyconnections.com/us-surrogacy-law-map/ rhode-island (last visited Apr. 27, 2017); South Carolina, Mid-S. Ins. Co. v. Doe, 274 F. Supp. $2 d 757$ (D.S.C. 2003) (holding a surrogacy contract determines the intent of the parties, implying the contract to be valid agreement), South Dakota, compensated surrogacy is permitted since no statute or published case law prohibits it. Gestational Surrogacy in South Dakota, CREATIVE FAMILY CONNECTIONS, http://www.creativefamilyconnections.com/us-surrogacylaw-map/south-dakota (last visited Apr. 27, 2017); Tennessee, surrogacy is defined by TENN. CODE ANN. $\$$ 36-1-102(50), but this section does not expressly allow or disallow surrogacy contracts. Where intended parents use their own gametes, they are considered the lega parents, see In re C.K.G. 173 S.W.3d 714 (Tenn. 2005); Texas, TEX. FAM. CODE ANN. §§ 160.751 to 160.763 (2005) (allowing gestational surrogacy); Utah, UTAH CODE ANN. § 78B-15-801 (2008) (allowing gestational surrogacy); Vermont, compensated surrogacy is permitted since no statute or published case law prohibits it. Gestational Surrogacy in Vermont, CREATIVE FAMILY CONNECTIONS, http://Www.

creativefamilyconnections.com/us-surrogacy-law-map/ vermont (last visited Apr. 27, 2017); Virginia, VA. CODE ANN. § 20-159 (2000) (legalizing gestational surrogacy); Washington, WASH. REV. CODE § 26.26 .240 (implicitly permitting uncompensated surrogacy but prohibiting surrogacy compensation beyond medical expenses and lawyer fees); WASH. REV. CODE § 26.26 .250 (imposing gross misdemeanor penalty for violation); West Virginia, W. VA. CODE §61-2-14h(e)(3) (2016); Wisconsin, Rosecky v. Schissel, 833 N.W.2d 634 (Wis. 2013) (holding surrogacy contracts are enforceable unless they are contrary to the child's best interests); Wyoming compensated surrogacy is permitted since no statute or published case law prohibits it, but as a practical matter gestational surrogacy is rare in Wyoming, Gestational Surrogacy in Wyoming, CREATIVE FAMILY

CONNECTIONS, http://www.creativefamilyconnections. com/us-surrogacy-law-map/wyoming (last visited Apr. 27, 2017)

${ }^{48}$ Interview with New York attorney, supra note 18; see also Anemonia Hartocollis, And Surrogacy Makes 3: In New York, a Push for Compensated Surrogacy, N.Y. TIMES (Feb. 19, 2014), https://www.nytimes. com/2014/02/20/fashion/In-New-York-Some-CouplesPush-for-Legalization-of-Compensated-Surrogacy.html; Alex Kuczynsky, Her Body, My Baby, N.Y. TIMES (Nov. 28, 2008), http://www.nytimes.com/2008/11/30/

magazine/30Surrogate-t.html.

${ }^{49}$ Interview with New York attorney, supra note 18; see Hodas v. Morin, 814 N.E.2d 320 (Mass. 2004).
${ }^{\circ}$ UNIF. CHILD CUSTODY JURISDICTION \& ENFORCEMENT ACT § 201(a)(1) (UNIF LAW COMM'N 1997). Under this act, a child's home state is the state with jurisdiction to make the initial child-custody determinations. The act defines the "home state" for a child who is less than six months old as the state in which the child has lived from birth.

See, e.g., P.G.M. v. J.M.A. (In re Baby Boy A.), 2007 Minn. App. Unpub. LEXIS 1189, *1 (Minn. Ct. App. Dec. $11,2007)$.

${ }^{2} 2 \mathrm{See}$, e.g., In the Matter of the Adoption of Children Whose First Names Are J.J. H.C., 44 Misc.3d 297 (N.Y. Fam. Ct. April 3, 2014)

N.Y. TASK FORCE, Surrogate Parenting, supra note 8 , at 138.

${ }^{54} / d$. at 74 .

${ }_{5}^{5}$ See, e.g., Jen Christensen, Record Number of Women Using IVF to Get Pregnant, CNN (Feb. 18, 2014), http:// www.cnn.com/2014/02/17/health/record-ivf-use/index. html.

${ }^{56}$ TASK FORCE ON LIFE AND THE LAW, NEW YORK STATE DEPARTMENT OF HEALTH, EXECUTIVE SUMMARY OF ASSISTED REPRODUCTIVE TECHNOLOGIES: ANALYSIS AND RECOMMENDATIONS FOR PUBLIC POLICY (2011), available at https://www.health.ny.gov/regulations/task force/reports_publications/execsum.htm.

${ }^{57}$ N.Y. TASK FORCE, Surrogate Parenting, supra note 8 , at

Id. at 23

${ }^{9}$ CPSA § 581-303(A).

${ }^{60} / d$. § 581-103(G).

${ }^{61}$ N.Y. TASK FORCE, Surrogate Parenting, supra note 8, at

${ }^{3}$ V. Jadva, L. Blake, P. Casey \& S. Golombok, Surrogacy families 10 years on: relationship with the surrogate, decisions over disclosure and children's understanding of their surrogacy origins, 27:10 HUMAN REPROD. 3008 (2012); S. Golombak, C. Murray, V. Jadva, E. Lycett, F. MacCallum \& J. Rust, Non-genetic

and non-gestational parenthood: consequences for parent-child relationships and the psychological wellbeing of mothers, fathers and children at age 3, 21:7 HUMAN REPROD. 1918 (2006); Susan Golombok, Fiona MacCallum, Clare Murray, Emma Lycett \& Vasanti Jadva, Surrogacy families: parental functioning, parent-child relationships and children's psychological development at age 2, 47:2 J. CHILD PSYCHOL. \& PSYCHIATRY 213 (2006); Katherine H. Shelton et al., Examining differences in psychological adjustment problems among children conceived by assisted reproductive technologies, 33:5 INT'L J. BEHAV. DEV. 385 (2009).

${ }^{64} \mathrm{~V}$. Jadva \& S. Imrie, Children of surrogate mothers: psychological well-being, family relationships and experiences of surrogacy, 29:1 HUMAN REPROD. 90 (2014)

${ }^{65}$ N.Y. TASK FORCE, Surrogate Parenting, supra note 8, at 77 .

${ }^{6}$ See Keston Ott-Dahl, Why Surrogacy Laws Must Be Established - the Story of the Ott-Dahls, HUFFINGTON POST (Mar. 29, 2017, 6:47 PM), http://www.

huffingtonpost.com/keston-ottdahl/why-surrogacy-lawsmust-b_b_9413418.html.

${ }^{67}$ CPSA § 581-405(A)(7)(II)(A).

${ }^{68}$ Interview by Cornell International Human Rights Clinic with New York surrogacy attorney (Feb. 2, 2017).

${ }^{69}$ N.Y. Task Force, Surrogate Parenting, supra note 8, at

80-81.

$70 / d$. at 81 .

"Obergefell v Hodges, 135 s. Ct. 2584 (2015).

N.Y. Task Force, Surrogate Parenting, supra note 8, at 84-85.

${ }^{74} / d$.

$5 / d . \S 581-406(A)$

${ }^{6}$ N.Y. TASK FORCE, Surrogate Parenting, supra note 8, at 88 .

${ }^{78}$ Elly Teman, The Social Construction of Surrogacy

Research: An Anthropological Critique of the

Psychosocial Scholarship on Surrogate Motherhood, 67 SOC. SCI. \& MED. 1104, 1104 (2008).

${ }^{80} / d$.; Vasanti Jadva, Clare Murray, Emma Lycett, Fiona MacCallum \& Susan Golombok, Surrogacy: the experiences of surrogate mothers, 18:10 HUMAN REPROD. 2196 (2003); Vasanti Jadva, Susan Imri \& Susan Golombok, Surrogate mothers 10 years on: a longitudinal study of psychological well-being and relationships with the parents and child, 30:2 HUMAN REPROD. 373 (2015)

${ }^{81}$ Karen Smith Rotabi \& Nicole F. Bromfield, From 
Intercountry Adoption to Global Surrogacy (2017) ${ }^{82}$ CPSA § 581-404(A)(3).

${ }^{83} / d$. § 581-404(A)(1)

${ }^{84}$ Europe: Albania, Sonia Allen, Governing Transnational Surrogacy Practices: What Role Can National and International Regulation Play, in BABIES FOR SALE? TRANSNATIONAL SURROGACY, HUMAN RIGHTS AND THE POLITICS OF REPRODUCTION 342, 346 (Miranda Davies ed., 2017) [hereinafter BABIES FOR SALE?]; Armenia, George S. Yacoubian, Jr. \& Lucy Clements, An Examination of Compliance with the Inter-country Adoption Convention: Exploring Surrogacy in Armenia as a Form of Human Trafficking, 31 Ariz. J. Int'l. \& Comp. L. 811, 831-32 (2014); Austria, Erich Geiessler \& Mariella Hager, Changing Direction: The Struggle of Regulating Assisted Reproductive Technology in Austria, REPROD. BIOMEDICINE AND SOC'Y ONLINE, http://Www. sciencedirect.com/science/article/pii//52405661817300059; Azerbaijan, SURROGACY, LAW AND HUMAN RIGHTS 131 (Paula Gerber \& Katie O'Byrne eds., 2015) [hereinafter SURROGACY, LAW AND HUMAN RIGHTS]; S. LUi \& E. Blyth, P-065 Infertility Patients' Motivations for and Experiences of Cross Border Reproductive Care: $A$ Preliminary Report, 26 HUMAN REPROD. 148, 148-149 (2011); Belarus, France Winddance Twine, OUTSOURCING THE WOMB: RACE, CLASS AND GESTATIONAL SURROGACY IN A GLOBAL MARKET 5 (2d ed. 2015) [hereinafter OUTSOURCING THE WOMB] Belgium, OUTSOURCING THE WOMB at 72; Bosnia and Herzegovina, Doroteya Nicolova, Women Head East for Wombs to Rent, BALKAN INSIGHT (Oct. 28, 2010), http:// www.balkaninsight.com/en/article/women-head-eastfor-wombs-to-rent; Bulgaria, OUTSOURCING THE WOMB at 72; Croatia, SURROGACY, LAW AND HUMAN RIGHTS at 131; Cyprus, Law on the Application of Medically Assisted Human Reproduction of 2015 (Law 69(I)/2015) (Cyprus); Czech Republic, No one wants Czech child born to surrogate mother, PRAGUE DAILY MONITOR (Aug. 13, 2015), http://praguemonitor.com/2015/08/13/ pr\%C3\%A1vo-no-one-wants-czech-child-born-surrogatemother; Denmark, EUR. PARL. POL'Y DEP'T: CITIZENS' RTS. AND CONST. AFF., A comparative study on the regime of surrogacy in EU member states 1, 15 (2013); SURROGACY, LAW AND HUMAN RIGHTS, at 132; Estonia, ESTONIA PENAL CODE § 132; Finland, SURROGACY, LAW AND HUMAN RIGHTS at 131; France, Code Civil [C. Civ.]
[Civil Code] art. 16-5, 16-7 (Fr.); Georgia, Law of Georgia on Health Protection (Georgia Article 143; SURROGACY, LAW AND HUMAN RIGHTS at 132; Germany, Susanne L. Gossl, Germany, in INTERNATIONAL SURROGACY ARRANGEMENTS 131, 131-32 (Katarina Trimmings \& Paul Beaumont, eds. 2013); Greece, SURROGACY, LAW AND HUMAN RIGHTS at 132; Hungary, SURROGACY, LAW AND HUMAN RIGHTS at 132; Iceland, Vala Hafstad, Supreme Court to Rule in First Surrogacy Case, ICELAND REV. ONLINE (Mar. 24, 2017), http://icelandreview.com/ news/2017/03/24/supreme-court-rule-first-surrogacy-case Ireland, BABIES FOR SALE? at 346; Italy, Legge 26 febbraio 2004, n.45, art. 12 G.U. Feb. 27,2004 (It). Latvia, OUTSOURCING THE WOMB at 72; Litchenstein, BABIES FOR SALE? at 346; Lithuania, BABIES FOR SALE? at 347; Luxembourg, Oliver P. Hance \& Alexandra Becheikh, Gestational Surrogacy in the Grand Duchy of Luxembourg, HANDBOOK OF GESTATIONAL

SURROGACY 189 (Scott Sills ed., 2016); Macedonia, Dragica Hristova, Surrogate Motherhood in Macedonia REPUBLIKA (Nov. 17, 2014), http://english.republika.mk/ surrogate-motherhood/; Malta, OUTSOURCING THE WOMB at 72; Moldova, Church of Moldova does not approve of surrogacy, INT'L REPROD. TECH. (Jan. 6 , 2014), http://www.irtsa.com.ua/en/news/873.html; Monaco, Christine Pasquier-Ciulla, Family law in Monaco: overview, THOMAS REUTERS PRAC. L. (2017), https://uk. practicallaw.thomsonreuters.com/8-616-4538? IrTS=201 $70424192927593 \&$ bhcp $=1 \&$ transitionType $=$ Default\&con extData=(sc.Default); Montenegro, Doroteya Nicolova, Women Head East for Wombs to Rent, BALKAN INSIGHT (Oct. 28, 2010), http://www.balkaninsight.com/en/article/ women-head-east-for-wombs-to-rent; Netherlands, OUTSOURCING THE WOMB at 72; Norway, Isak Ladegaard, Surrogacy changers perception of family, SCIENCE NORDIC (2013), http://sciencenordic.com/ surrogacy-changes-perception-family; Poland, EUR. PARL. POL'Y DEP'T: CITIZENS' RTS. AND CONST. AFF., $A$ comparative study on the regime of surrogacy in EU member states 1, 16 (2013); Portugal, Portugal legalized surrogacy for infertile women, INSIDE THE WORLD (2016), https://www.insidetheworld.org/2016/07/20/ portugal-legalized-surrogacy-for-infertile-women/ Romania, The Romanian Parliament Focuses on Map and Surrogacy, GĖNÉTHIQUE (Mar. 24, 2016), http://www. genethique.org/en/romanian-parliament-focuses-map-
and-surrogacy-65248.htm|\#.WP5VD1PyvjB; Russia, OUTSOURCING THE WOMB at 4; San Marino, G. Shannon et al., ADOPTION - LAW AND PRACTICE UNDER THE REVISED EUROPEAN CONVENTION ON THE ADOPTION OF CHILDREN 143 (2014); Serbia, BABIES FOR SALE? at 346; Slovakia, EUR. PARL. POL'Y DEP'T.: CITIZENS' RTS. AND CONST. AFFAIRS, A comparative study on the regime of surrogacy in EU member states 1, 16 (2013), Slovenia, BABIES FOR SALE? at 346; Spain, SURROGACY, LAW AND HUMAN RIGHTS at 131; Sweden, SURROGACY, LAW AND HUMAN RIGHTS at 131; Switzerland, BABIES FOR SALE? at 346; A child is not a commodity, says top Swiss court, SWISS INFO (July 30, 2015), http://www. swissinfo.ch/eng/

surrogate-law_a-child-is-not-a-commodity--says-topswiss-court/41575816; Turkey, SURROGACY, LAW AND HUMAN RIGHTS at 131; Aref Abu-Rabia, Infertility and Surrogacy in Islamic Society: Socio-Cultural,

Psychological, Ethical, and Religious Dilemmas, 6 OPEN PSYCHOL. J. 54, 58 (2013) [hereinafter Surrogacy in Islamic Society]; Ukraine, FAMILY CODE OF UKRAINE Art. 123.2 (Ukr.); United Kingdom, OUTSOURCING THE WOMB at 5; The Surrogacy Arrangements Act 1985 (U.K.). South America: Argentina, Fabina Marcela Quaini, Gestational Surrogacy in Argentina, HANDBOOK OF GESTATIONAL SURROGACY 99 (Scott E. Sills ed., 2016); Brazil, Lucas Pesso Feniman, Surrogacy in Brazil: issues in legal research 1, 3 (Jan. 23, 2015); Chile, Daniela Horvitz Lennon, Family law in Chile: overview, THOMAS REUTERS PRAC. L. (2017), https://uk.practicallaw. thomsonreuters.com/9-568-3568?_IrTS=2017041514510 9220\&transitionType $=$ Default\&contextData $=$ (sc. Default \& firstPage=true \&bhcp $=1$; Colombia Reproductive Laws in Colombia, GLOBAL IVF, http:// www.globalivf.com/directory/laws/colombia/; Paraguay INT'L. FED'N. OF FERTILITY SOC'Y., IFFS Surveillance 2016, 1 GLOBAL REPROD. HEALTH 71-73 (Steven J. Ory ed., 2016) [hereinafter IFFS 2016]; Peru, SURROGACY, LAW AND HUMAN RIGHTS at 132; Uruguay, Uruguayan Parliament approves law for free in vitro fertilization and surrogacy, LIFE SITE (Nov. 21, 2013), https://www. lifesitenews.com/news/uruguayan-parliament-approveslaw-for-free-in-vitro-fertilization-and-surro; BABIES FOR SALE? at 346; Venezuela, IFFS 2016 at 71-73. North America: Barbados, IFFS 2016 at 71-73; Canada, OUTSOURCING THE WOMB at 4-5; Dominican Republic,
Hague Conf. on Priv. Int'I. L., Questionnaire on the Private International Law Issues Surrounding the Status of Children, Including Issues Arising from International Surrogacy Agreements, April 2013, available at https:/l assets.hcch.net/upload/wop/gap2014pd3do.pdf; El Salvador, SURROGACY, LAW AND HUMAN RIGHTS at

131; Guatemala, Jamie Tecu \& Eleonara Lamm, Guatemala, in INTERNATIONAL SURROGACY AGREEMENTS: LEGAL REGULATION AT THE INTERNATIONAL LEVEL 172 (Katarina Trimmings \& Paul Beaumont eds., 2013); Honduras, IFFS 2016 at 71-73; Jamaica, Sherry Ann McGregor, The Legal Challenges Surrounding Surrogacy, GLEANER (Sep. 1, 2014), http:// jamaica-gleaner.com/article/flair/20140901/legalchallenges-surrounding-surrogacy; Mexico, Eleonara Lamm, Mexico, in INTERNATIONAL SURROGACY AGREEMENTS: LEGAL REGULATION AT THE INTERNATIONAL LEVEL 255, 255-56 (Katarina Trimming \& Paul Beaumont eds. 2013); Panama, DEAN A. MURPHY, GAY MEN PURSUING PARENTHOOD THROUGH SURROGACY 54 (2015); Trinidad and Tobago, Respondent to IFFS Survey noted that surrogacy was neither permitted nor ever performed. IFFS 2016 at 71 73. Australia \& Oceania: Australia, Mary Keyes, Australia, in INTERNATIONAL SURROGACY AGREEMENTS: LEGAL REGULATION AT THE INTERNATIONAL LEVEL 25, 25-26 (Katarina Trimmings \& Paul Beaumont eds., 2013); New Zealand, Claire Achmad, Australia, in INTERNATIONAL SURROGACY AGREEMENTS: LEGAL REGULATION AT THE INTERNATIONAL LEVEL 295, 295-96 (Katarina Trimmings \& Paul Beaumont eds., 2013). Africa: Algeria, SURROGACY, LAW AND HUMAN RIGHTS at 131; Botswana, Mpho Mokwape, Pioneering surrogacy case tests local judiciary, MMEGI ONLINE (July 22, 2016), http://www.mmegi.bw/index.php?aid=61713\&dir=2016/ july/22; Cameroon, IFFS 2016 at 71-73; Egypt, Margaret Ryznar, International Commercial Surrogacy and its Parties, 43 J. MARSHALL L. REV. 1009, 1016 (2010); Hend El-Behary, A Mother for Nine Months: Surrogacy on the Rise in Egypt, Despite Legal ban, EGYPT INDEPENDENT (Oct. 23, 2016), http://www.egyptindependent.com/ news/mother-nine-months-surrogacy-rise-egypt-despite legal-ban on 26.4.2017; Ethiopia, SURROGACY, LAW AND HUMAN RIGHTS at 131; Girum Tebeje, Surrogacy is becoming rife in Ethiopia, DIRE TUBE (June 7, 2014), 

becoming-rife-in-ethiopia_5413.html; Ghana, Kobby Blay, MoH Seeks Regulation on Surrogacy, GHANA HEALTH NEST (Apr. 21, 2016), http://ghanahealthnest. com/moh-seeks-legislation-surrogacy-ghana-healthsegbefial; Kenya, Daniel Wesangula, Will Key Ruling on Surrogacy Shed More Light?, STANDARD DIGITAL (Mar. 20, 2016) https:/wwwstand STANDARD Ditial (N article/2000195477/will-key-ruling-on-surrogacy-shedmore-light; Mali, IFFS 2016 at 71-73; Mauritius, SURROGACY, LAW AND HUMAN RIGHTS at 131;

Morocco, BABIES FOR SALE? at 346; Nigeria, Odidika Ugochukwu Joannes Umeora, Maryjoanne Chinyem Umeora, Nkechi Bridget Emma-Echiegu \& Felix Nzube Chukwuneke, Surrogacy in Nigeria: Legal, Ethical, Socio cultural, Psychological and Religious Musings, 13 AFR. MED. \& HEALTH SCI. 105, 105-09 (2014); Senegal The Senegalese respondent to the IFFS survey noted that surrogacy was not permitted and never occurs. IFFS 2016 at 71-73; South Africa, Children's Act, 2005 Act No. 38 of 2005 (S. Afr.), available at http://www.justice.gov.za/ legislation/acts/2005-038\%20childrensact.pdf.; Xinran Cara Tang, Setting Norms: Protection for Surrogates in International Commercial Surrogacy, 25 MINN. J. INT'L. L. 193, 197 (2016); Tanzania, Cecilia Assey, Surrogacy and the Right to Family in Tanzania, ACADEMIA, https:// www.academia.edu/23353990/SURROGACY_AND_THE RIGHT_TO_FAMILY_IN_TANZANIA; Uganda, BABIES FOR SALE? at 349; Zimbabwe, Coddy Fungai Nyamundada, Legal Matters: Wombs for Rent: Surrogacy Agreements, SUNDAY MAIL (Feb. 7, 2016), http://www.sundaymail.co. zw/legal-matters-wombs-for-rent-surrogacy-

agreements/. Asia: Afghanistan, SURROGACY, LAW AND HUMAN RIGHTS at 131; Armenia, Gayane Abrahamyan, Birth Rights and Concerns: Issue of surrogate birthing raises debate, ARMENIA NOW (July 3, 2012), http://www. armenianow.com/society/36243/armenia_surrogate

mothers_legislation; BABIES FOR SALE? at 349-50;

Azerbaijan, SURROGACY, LAW AND HUMAN RIGHTS at 131; S. Lui \& E. Blyth, P-065 Infertility Patients' Motivations for and Experiences of Cross Border Reproductive Care: A Preliminary Report, 26 HUMAN REPROD. 148, 148-149 (2011); Bahrain, SURROGACY, LAW AND HUMAN RIGHTS at 131; Bangladesh, SURROGACY, LAW AND HUMAN RIGHTS at 131; Bhutan، Damchoe Pem, Bhutan Unwittingly Has First Surrogate
Birth, BHUTANESE (Nov. 5, 2016), http://thebhutanese. bt/bhutan-unwittingly-has-first-surrogate-birth/; Cambodia, Kuch Naren, Prime Minister Warns Mothers Against Surrogacy in Midst of Ban, CAMBODIA DAILY (Feb. 22, 2017), https://www.cambodiadaily.com/ morenews/prime-minister-warns-mothers-againstsurrogacy-in-midst-of-ban-125583/; China, BABIES FOR SALE? at 334, Alice Yan, Official Ban is No Break on China's Surrogacy Sector, CNBC (Feb. 16, 2017), http:// www.cnbc.com/2017/02/16/official-ban-is-no-brake-onchinas-surrogacy-sector.html; India, Normann Wizleb \& Anurag Chawla, Surrogacy in India: Strong Demand, Weak Laws, in SURROGACY, LAW, AND HUMAN RIGHTS 167, 168-176; Indonesia, SURROGACY, LAW AND HUMAN RIGHTS at 131; Iran, Religious decree that a judge must deliver judgment based on in the absence of relevant codified law. QANUNI ASSASSI JUMHURI ISLAMAI IRAN [THE CONSTITUTION OF THE ISLAMIC REPUBLIC OF IRAN] art. 1671358 [1980] (Iran): Surrogacy in Islamic Society at 6; Israel, Embryo Carrying Agreements (Approval of the Agreement and the Status of the Child) Law, SH No. 1577 p. 176 (Isr.), Avishalom Westreich, Changing Motherhood Paradigms: Jewish Law, Civil Law and Society, 28 HASTINGS WOMEN'S L. J. 97, 103 (2017), Abraham Benshusham \& Joseph G. Schenker, Legitimizing Surrogacy in Israel, 12 J. HUMAN REPROD. 1832, 1832-34 (1997), Daphna BirenbaumCarmeli, Contested Surrogacy and the Gender Order, 3 J. MIDDLE EAST WOMEN'S STUD. 21, 38 (2007); Japan, SURROGACY, LAW AND HUMAN RIGHTS at 131; Jordan, SURROGACY, LAW AND HUMAN RIGHTS at 131; Kazakhstan, BABIES FOR SALE? at 339; Kuwait, SURROGACY, LAW AND HUMAN RIGHTS at 131; Surrogacy in Islamic Society at 6; Kyrgyzstan, Surrogacy Law and Human Rights at 132; Laos, Roseanna Gerin Laos Govt. Shuts Down Clinic Suspected of Providing Illegal Surrogacy Services; Exploitation of Women Feared, BUS. \& HUMAN RTS. RESOURCE CTR. (June 8 , 2017), https://business-humanrights.org/en/laosconcerned-with-exploitation-of-women-govt-shutsdown-clinic-suspected-of-providing-illegal-surrogacyservices-joint-efforts-with-thai-and-cambodia-officialpursued-to-tackle; Lebanon, Surrogacy not an option in Lebanon, LEB. NEWS (Sep. 13, 2014), http://www. dailystar.com.lb/News/Lebanon-News/2014/Sep13/270527-surrogacy-not-an-option-in-lebanon.ashx; alaysia, SURROGACY, LAW AND HUMAN RIGHTS at 131; Maldives, SURROGACY, LAW AND HUMAN RIGHTS t 131; My border, NATION (Apr. 25, 2017), http://www. nationmultimedia.com/news/opinion/today_ editorial/30313268; Nepal, National Health Policy 2071, pt. 12 cl. 14, 2014 (Nepal); Supreme Court of Nepal, Case 072-WO-0119 (2016); Oman, SURROGACY, LAW AND HUMAN RIGHTS at 131; Surrogacy in Islamic Society at 6; Pakistan, OUTSOURCING THE WOMB at 4; Phillipines, Senate Bill No 2344, Thirteenth Republic of Philippines (Phil.), available at www.senate.gov.ph/ lisdata/54884531!.pdf; Qatar, SURROGACY, LAW AND HUMAN RIGHTS at 131; Surrogacy in Islamic Society at 6; Saudi Arabia, SURROGACY, LAW AND HUMAN RIGHTS at 131; Surrogacy in Islamic Society at 6; Singapore, SURROGACY, LAW AND HUMAN RIGHTS at 131: South Korea, SURROGACY, LAW AND HUMAN RIGHTS at 132 Sri Lanka, SRI LANKA MED. COUNCIL, Assisted Reproductive Technologies: A Provisional Code of Practice (2005) (Sri Lanka), available at http://www. srilankamedicalcouncil.org/download/download/6/66db9 284166164d13be1684c657835bc.pdf; Syrian Arab Republic, SURROGACY, LAW AND HUMAN RIGHTS at 131; Surrogacy in Islamic Society at 6; Taiwan, SURROGACY, LAW AND HUMAN RIGHTS at 131;

Tajikstan, BABIES FOR SALE? at 346; Thailand, Child Born Out of Assisted Reproductive Technology Protection Act B.E. 2558 (Thai.), Jessica M. Caamano, International Commercial Gestational Surrogacy through the eyes of Children born to Surrogates in Thailand: A Cry for Legal Attention, 96 B.U. L. REV. 571, 598 (2016); Turkey Surrogacy, Law and Human Rights, at 131; Surrogacy in Islamic Society, at 6; Turkmenistan, SURROGACY, LAW AND HUMAN RIGHTS at 131; Surrogacy in Islamic Society at 6; United Arab Emirates, SURROGACY, LAW AND HUMAN RIGHTS at 131; Surrogacy in Islamic Society at 6; Vietnam, SURROGACY, LAW AND HUMAN RIGHTS at 131; Yemen, SURROGACY, LAW AND HUMAN RIGHTS at 131; Surrogacy in Islamic Society at 6.

${ }^{85}$ CODE CIVIL [C. CIV] [CIVIL CODE] art. 16-5, 16-7 (Fr.) ${ }^{86}$ EUR. PARL. POL'Y DEP'T: CITIZENS' RTS. AND CONST. AFF., A comparative study on the regime of surrogacy in EU member states 1, 15 (2013) [hereinafter EU Review] ${ }^{87}$ Legge 26 febbraio 2004, n.45, art. 12 G.U. Feb. 27 2004 (It.).
${ }^{8}$ EU Review, supra note 91 , at 16. ${ }^{89}$ Prohibits egg donation, so therefore prohibits gestational surrogacy. Id. at 1, 101, 104.

${ }^{90}$ EU Review, supra note 91 , at 15.

${ }^{91}$ See Vala Hafstad, Supreme Court to Rule in First Surrogacy Case, ICELAND REV. ONLINE (Mar. 24, 2017), http://icelandreview.com/news/2017/03/24/supremecourt-rule-first-surrogacy-case.

${ }^{92}$ EU Review, supra note 91 , at 15.

${ }^{93}$ Isak Ladegaard, Surrogacy changes perception of family, SCIENCE NORDIC (2013), http://sciencenordic.com/ surrogacy-changes-perception-family.

${ }_{94}$ EU Review, supra note 91 , at 16 ${ }_{95} / d$.

${ }^{9} / d$.

id.

${ }_{98}^{8}$ See SARAH-VAUGHAN BRAKMAN \& DARLENE FOZARD WEAVER, THE ETHICS OF EMBRYO ADOPTION AND THE CATH. TRADITION: MORAL ARGUMENTS, ECONOMIC REALITY AND SOCIAL ANALYSIS 301 (2008). ${ }^{99}$ Isabelle Rein Lescastereyres, Recognition of the parent child relationship as a result of surrogacy and the best interest of the child: How will France adapt after the ECtHR rulings, 16 ERA F. 149, 150 (2015). ${ }^{100}$ Convention for the protection of Human Rights and Dignity of the Human Being with regard to the Application of Biology and Medicine: Convention on Human Rights and Biomedicine, Apr. 4, 1997, Eur. T.S. No. 164, 36 I.L.M. 817 (1997); see also Roberto Andorno, The Oviedo Convention: A European Legal Framework at the Intersection of Human Rights and Health Law, 2 J. INT'L. BIOTECH. L. 133 (2005).

${ }^{101}$ Andorno, supra note 105.

${ }^{102}$ See Mennesson v. France, no. 65192/11 Eur. Ct. H.R. (2014); Labassee v. France, no. 65941/11 Eur. Ct. H.R. (2014); Laborie v. France, no. 44024/13 Eur. Ct. H.R. (2017).

${ }^{103}$ Paradiso v. Italy, no. 25358/12 Eur. Ct. H.R. (2015). ${ }^{104}$ U.S. EMBASSY IN NEPAL, Surrogacy Services are Banned in Nepal, https://np.usembassy.

gov/u-s-citizen-services/local-resources-of-u-s-citizens/ surrogacy-in-nepal/ (last visited July 8, 2017).

${ }^{105}$ Thailand bans commercial surrogacy for foreigners BBC NEWS (Feb. 20, 2015), http://www.bbc.com/news/ world-asia-31546717.

${ }^{106}$ Nehaa Chaudhari, Regulating Assisted Reproductive 
Technologies in India, OXFORD HUMAN RTS. HUB (November 12, 2015), http://ohrh.law.ox.ac.uk/

regulating-assisted-reproductive-technologies-in-india. ${ }^{107}$ Victoria Burnett, As Mexican State Limits Surrogacy Global System is Further Strained, N.Y. TIMES (Mar. 23, 2017), https://www.nytimes.com/2017/03/23/world/ americas/as-mexican-state-limits-surrogacy-globalsystem-is-further-strained.html.

${ }^{108}$ Rachel Abrams, Nepal Bans Surrogacy, Leaving Couples With Few Low-Cost Options, N.Y. TIMES (May 2 2016), https://www.nytimes.com/2016/05/03/world/asia/ nepal-bans-surrogacy-leaving-couples-with-few-lowcost-options.html.

${ }^{109}$ Child Born Out of Assisted Reproductive Technology Protection Act B.E. 2558 (Thai.), available at http://www loc.gov/law/foreign-news/article/thailand-new-

surrogacy-law/; Thailand bans commercial surrogacy, supra note 110.

${ }^{10}$ Supreme Court of Nepal, Case 072-WO-0119 (July 14 2016) (Nepal).

"11 Sophie Jain Evans, Israeli military airlift flies babies born to surrogate mothers in Nepal for gay Israel couples out of quake zone, DAILY MAIL (Apr. 28, 2015) http://www.dailymail.co.uk/news/article-3058241/Babiesborn-surrogate-mothers-Nepal-gay-lsraeli-couplesflown-country-military-planes-following-quake. html\#ixzz4cn3w1DW7.

112 Bindu Shajan Perappadan, A setback for surrogacy in India?, HINDU (Nov. 29, 2015), http://www.thehindu com/opinion/op-ed/a-setback-for-surrogacy-in-india/ article7927730.ece.

${ }^{13}$ See Rama Lakshmi, India to propose a ban on commercial surrogacy, ending a lucrative business, WASH. POST (Aug. 24, 2016), https://www. washingtonpost.com/world/rent-a-womb-industry-inindia-may-be-shut-down/2016/08/24/39684d60-79e3

42c9-893d-9ff5998ce179_story.html?utm_term= ce49c475f98f

${ }^{114}$ Cabinet approves bill to prohibit commercial surrogacy, Sushma Swaraj slams celebrities for misusing practice, INDIAN EXPRESS (Aug. 25, 2016), http:// indianexpress.com/article/india/india-news-india/ surrogacy-bill-2016-sushma-swaraj-slams-celebrities-formisusing-practice/.

${ }^{15}$ India unveils plans to ban surrogacy, BBC NEWS (Aug. 25, 2016), http://www.bbc.com/news/world-asia- india-37182197.

${ }^{116}$ Georgia Seeks to Attract Surrogacy Tourism, INT'L MED. TRAVEL J. (Aug. 28, 2015), https://www.imtj.com/ news/georgia-seeks-attract-surrogacy-tourism/.

${ }^{117}$ EU Review, supra note 91, at 16.

${ }^{118}$ Family Code of Ukraine Art. 123.2 (Ukr.), available at http://www.refworld.org/pdfid/4c4575d92.pdf.

${ }^{119}$ Embryo Carrying Agreements (Approval of the Agreement and the Status of the Child) Law, SH No. 1577 p. 176 (Isr.).

${ }^{120} \mathrm{Abraham}$ Benshusham \& Joseph G. Schenker,

Legitimizing Surrogacy in Israel, 12:8 HUMAN REPROD. 1832, 1832-34 (1997).

${ }^{121}$ Nuphar Lipkin \& Etti Samama, ISHA L'ISHA-HAIFA FEMINIST CENTER, Surrogacy in Israel: Status Report 2010 and Proposals for Legislative Amendment (2014), available at http://isha.org.il/wp-content/ uploads/2014/08/surrogacy_Eng001.pdf.

${ }_{122}$ Joseph G. Schenker, Legal Aspects of ART Practice in Israel, 20:7 J. ASSISTED REPROD. \& GENETICS 250, (2003). ${ }^{123}$ ERIN NELSON, LAW, POLICY AND REPRODUCTIVE AUTONOMY, n.254 (2013)

${ }^{124}$ Katarina Lee \& Laura Gotti Tedeschi, Worldwid Surrogacy Laws, CORETHICS, http://corethics.org/wpcontent/uploads/Surrogacy-Laws.pdf (last visited July 8, 2015).

${ }^{125}$ Children's Act, 2005 Act No. 38 of 2005 (S. Afr.) available at http://www.justice.gov.za/legislation/

acts/2005-038\%20childrensact.pdf.

${ }^{126} / d$. $\$ 295$

${ }^{127}$ Id. $\$ 292$.

${ }^{128}$ U.S. CONST. art. VI, cl. 2.

129 United Nations Convention on the Rights of the Child

on Sale of Children, Child Prostitution, and Child

Pornography (Optional Protocol 2), ratified December

$23,2002$.

${ }^{130} / d$. at art. 1, ratified December 23, 2002; John Tobin.

To Prohibit or Permit: What is the (Human) Rights

Response to the Practice of International Commercia

Surrogacy? 63 Int'I. Comp. L. Q. 336 (2014).

${ }^{131} / d$. at art. 2.A.

${ }^{132}$ United Nations Convention on the Rights of the Child signed February 16, 1985

${ }_{133} / d$. at art. 2 .

${ }^{134}$ CPSA § 581-102.

${ }^{135}$ International Covenant on Civil and Political Rights art. 23(2), adopted Dec. 16, 1966, 999 U.N.T.S. 171 (entered into force Mar. 23, 1976): S. COMM. ON

FOREIGN REL., Report on the International Covenant on Civil and Political Rights, S. Exec. Rep. No. 23, at 1 (102 Sess., 1992), reprinted in 31 I.L.M. 645 (1992).

${ }^{36}$ U.N. HUMAN RTS. COMM'N., U.N. Doc.

CCPR/C/85/D/1153/2003 (2005).

${ }^{137}$ International Covenant on Economic, Social and

Cultural Rights, adopted Dec. 16, 1966, 993 U.N.T.S. 3 (entered into force Jan. 3, 1976).

${ }^{138} / d$. at art. 12; Comm. on Econ., Soc., and Cultural Rts. General Comment No. 14 (2000), E/C.12/2000/4, at ๆ 8. As per the General Comment, the right includes freedom from "non-consensual medical treatment." As a corollary, it also includes the right to consent to medical treatment. See also Comm. on Econ., Soc., and Cultura Rts., General Comment 22 (2016), E/C.12/GC/22, ๆ 5, wherein the committee notes that Article 12 includes the "right to make free and responsible decisions and choices, free of violence, coercion and discrimination, regarding matters concerning one's body and sexual and reproductive health."

${ }^{139}$ Comm. on Econ., Soc., and Cultural Rts., General Comment 18 (2005), E/C. 12/GC/18, at 96. ${ }^{140}$ Convention on the Elimination of All Forms of Discrimination against Women, adopted Dec. 18, 1979, 1249 U.N.T.S. 13 (entered into force Dep. 3, 1981).

${ }^{141} / d$. at art. 16.

142 CPSA § 581-401(D)

${ }^{143}$ International Covenant on Civil and Political Rights art. 23(2), adopted Dec. 16, 1966, 999 U.N.T.S. 17 (entered into force Mar. 23, 1976).

${ }^{44}$ UN Human Rights Committee (UNHRC), CCPR General Comment No. 19: Article 23 (The Family) Protection of the Family, the Right to Marriage and Equality of the Spouses, 27 July 1990, १15.

${ }^{45}$ Obergefell v. Hodges, 135 S. Ct. 2584 (2015). 
